\title{
Growth, behaviour and cell toxin quota of Dinophysis acuta during a daily cycle
}

\author{
G. Pizarro ${ }^{1,3, *}{ }^{,}$L. Escalera ${ }^{1}$, S. González-Gil ${ }^{1}$, J. M. Franco ${ }^{2}$, B. Reguera ${ }^{1}$ \\ ${ }^{1}$ Instituto Español de Oceanografía, Centro Oceanográfico de Vigo, Aptdo. 1552, 36280 Vigo, Spain \\ ${ }^{2}$ Instituto de Investigaciones Marinas (CSIC), Eduardo Cabello 6, 36080 Vigo, Spain \\ ${ }^{3}$ Present address: Instituto de Fomento Pesquero-CEQUA, Enrique Abello 0552, Casilla 101, Punta Arenas, Chile
}

\begin{abstract}
In 2005, a bloom of the Diarrhoetic Shellfish Poisoning (DSP) causative agent Dinophysis acuta Ehrenberg in the Galician Rías Baixas (NW Spain) started in early August and reached

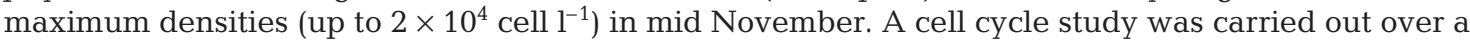
$22 \mathrm{~h}$ period on 9 and 10 November to describe the physiological status and the short-term variability in cell toxin quota of $D$. acuta at the time of the annual maximum of lipophilic toxins in shellfish. At that time, the population of $D$. acuta showed an extremely low division rate $\left(\mu=0.03 \mathrm{~d}^{-1}\right)$, a high frequency of dead cells (up to $15 \%$ ) and cells with starch granules (up to $93 \%$ ), and no evidence of recent mixotrophic behaviour. Still, the cells, which did not perform vertical migration, aggregated around salinity-driven density discontinuities in the top $5 \mathrm{~m}$ and had a high cell toxin quota (determined by liquid chromatography-mass spectrometry) for this species. A 3.5-fold difference was found between maximum (during the night) and minimum values of cell toxin quota. Okadaic acid (OA) was the predominant toxin and changes in cell quota of different toxins showed different daily patterns in the content of okadaiates and pectenotoxins; thus, the toxin profile is influenced by the time of sampling. Dissolved toxins (adsorbed by resins in passive samplers from 8 to 14 November) also reached annual maxima and reflected the vertical distribution of $D$. acuta cells. These results emphasize the need to parameterize physiological conditions and behaviour of Dinophysis populations during different phases of the population growth and hydrodynamic scenarios.
\end{abstract}

KEY WORDS: Dinophysis spp. Cell cycle $\cdot$ Cell toxin quota $\cdot$ DSP toxins $\cdot$ Okadaic acid $\cdot$ Diol-esters Pectenotoxins Resale or republication not permitted without written consent of the publisher

\section{INTRODUCTION}

The dinoflagellate species Dinophysis acuminata Claparède \& Lachmann and Dinophysis acuta Ehrenberg contain Diarrhoetic Shellfish Poisoning (DSP) toxins - e.g. okadaic acid (OA) and dinophysistoxins (DTXs) - and pectenotoxins that are transferred through the food web. Successive occurrences of these 2 species have led to prolonged closures of shellfish harvesting on European Atlantic coasts, in New Zealand and in Chile (Reguera \& Pizarro 2007). D. acuta is a common member of the late summer-autumn (August to November) phytoplankton assemblage in northwest Iberian coastal waters (Reguera et al. 1995,
Moita et al. 2006). In years when very hot summers and moderate upwelling allow the establishment of deeper thermoclines, this species replaces $D$. acuminata as the main DSP agent and leads to more prolonged shellfish closures (Escalera et al. 2006b). Maximum concentrations of $D$. acuta in the Galician Rías Baixas have been found under 2 different scenarios: (1) thermally driven stratification that allows for in situ division and (2) relaxation/downwelling conditions (at the end of the upwelling season in autumn) that favour along-shore and cross-shelf transport and a selective accumulation of large swimming dinoflagellates, including Dinophysis spp., inside the rías (Fraga et al. 1988, Figueiras et al. 1994). 
The long-term objective of any major programme focused on toxin-containing microalgae is to develop species-specific models to predict their occurrence, maintenance and dissipation, and to estimate the time and magnitude of accumulation and elimination of their toxins in affected shellfish resources. To apply biophysical models to a microalgal population, detailed information on the behaviour (diel vertical migration, feeding) and physiology (growth, life cycle transitions) of the selected species is required (Kamykowski et al. 1998). Additional information on the toxin profile and toxin content per cell (cell toxin quota, $Q_{t}$ ) is needed to model the uptake and detoxification kinetics of their toxins by different shellfish species (Blanco et al. 1995). Studies on vertical migration of Dinophysis spp. are scarce and most of them are not accompanied by physical records of water movements (Maestrini 1998); there is evidence of vertical migration of $D$. acuminata in the Galician Rias (Villarino et al. 1995, Reguera et al. 2003), but the same species in the same location may exhibit no vertical displacement at all under different environmental conditions and/or phases of population growth (L. Velo-Suárez unpubl. data). In contrast, D. norvegica Claparède \& Lachmann in the Baltic (Carpenter et al. 1995) and D. fortii Pavillard in Japan (Iwasaki 1986) have been reported to perform no diel vertical migration. Therefore, site and species-specific studies under different scenarios are required to gain knowledge of the adaptive strategies of each species throughout its growing season.

Difficulties in establishing cultures of phototrophic species of Dinophysis led to suspicions that they are mixotrophic. Remains of ciliates were found in the digestive vacuoles of $D$. acuminata, D. norvegica (Jacobson \& Andersen 1994) and D. fortii (Koike et al. 2000). Setälä et al. (2005) showed that D. acuminata populations located in deep $(>70 \mathrm{~m})$ waters in the Baltic Sea exhibited poor photosynthetic activity compared with populations from subsurface water layers. In the same region, Gisselson et al. (2002) found that D. norvegica cells aggregating in the thermocline at the 15 to $20 \mathrm{~m}$ depth had a division rate (up to $0.4 \mathrm{~d}^{-1}$ ) that could not be supported with the observed ${ }^{14} \mathrm{C}$ uptake rates. This observation and the presence of digestive vacuoles in 2 to $22 \%$ of the population led the authors to suggest that the thermocline may provide D. norvegica cells with their suitable prey. Recently, Park et al. (2006) discovered that the ciliate Mesodinium rubrum Lohmann (Myrionecta rubra Jankowski), grown with additions of cryptophytes of the genus Teleaulax, constituted an excellent prey for D. acuminata, leading to high division rates (up to $0.95 \mathrm{~d}^{-1}$ ) under continuous illumination in laboratory cultures. A key issue that awaits resolution is whether the phycoerythrin-containing chloroplasts in photo- trophic Dinophysis spp. are constitutive or whether they are kleptoplastids retained from their prey (Park et al. 2006). Nevertheless, a common feature described after mixotrophic behaviour of these species is the occurrence of digestive vacuoles. Most intriguing is the detection of starch granules, easily observed in lugolfixed samples (Jacobson \& Andersen 1994), which are conspicuous during late stages of Dinophysis populations (González-Gil et al. 2006). The physiological purpose of these granules within Dinophysis spp. is still unknown.

Studies on the toxin profile and toxin content of Dinophysis acuta by high performance liquid chromatography (HPLC) in plankton concentrates rich in this species and in single cell isolates showed that D. acuta strains and/or shellfish exposed to their blooms in Europe contained OA and DTXs. Dinophysistoxin-1 (DTX1) was found in Scandinavian strains and Dinophysistoxin-2 (DTX2) in those from Ireland, Spain and Portugal (Reguera \& Pizarro 2007). Recent studies with liquid chromatography-mass spectrometry (LC-MS) have shown a widespread presence of pectenotoxins (PTXs) in all D. acuta populations tested (Vale \& Sampayo 2002, Fernández-Puente et al. 2004, Miles et al. 2004a, MacKenzie et al. 2005, Fernández et al. 2006), and allowed the identification of new OA-related toxins (okadaiates), such as the C8 diolester of OA (OA-D8) in D. acuta from New Zealand (Suzuki et al. 2004). Deploying 'solid phase adsorbing toxins tracking' (SPATT) resins in the field, MacKenzie et al. (2004) showed that during algal blooms of Dinophysis spp., significant amounts of toxin - including low polarity lipophilic compounds such as the pectenotoxins and the okadaiates - were released into the seawater. It is difficult to estimate toxin-release rates in the open sea because the toxins adsorbed by the resins cannot be related either to Dinophysis concentrations or to water volume. Nevertheless, spatio-temporal variability in the amount of adsorbed toxins in SPATT units provides seasonal and species-specific patterns on toxin release in the water column, provided saturation of the resins is avoided.

Estimates of cell toxin quota in field populations of Dinophysis, without the quantification of released toxins, are based on the accumulation of toxin per cell, i.e. the balance between toxin production (or uptake) and release. The dilution effect of cellular division (Flynn \& Flynn 1995) should be considered, as well as the intracellular metabolism of the toxins to avoid autotoxicity (Hu et al. 1995a), parasitism (Bai et al. 2007), and enzymatic transformations during extraction (Quilliam et al. 1996). A major question arising from the work of Park et al. (2006) is whether toxins are produced de novo by Dinophysis or just taken up from their prey. No doubt the availability of prey will influence growth and, 
hence, the balance between growth and toxin accumulation. Unfortunately, there is no information on toxin content either in Mesodinium rubrum or in its cryptophyte prey, but red tides of this species, widespread in estuaries, fjords and upwelling areas, have never been associated with toxic outbreaks, and Mesodinium is used as feed in aquaculture (Yih et al. 2004).

During November 2005 we studied a dense bloom of Dinophysis acuta, accompanied by another Paralytic Shellfish Poisoning (PSP) toxin producer, Gymnodinium catenatum Graham, and other large dinoflagellates, in the Galician Rías Baixas (NW Spain). The bloom provided unique conditions for in situ observations on $D$. acuta behaviour, toxin profile and cell toxin quota, and allowed us to make other biological observations of a plankton population where this species was the overwhelmingly dominant species of Dinophysis. The main objective of this study was to describe the diel variability in toxin profile and cell toxin quota of $D$. acuta along with behavioural and cellular characteristics of a population that was in stationary/early decline phase but associated with annual maxima of toxin content in shellfish. This is the first time that the diel toxinological variability of a Dinophysis sp. (determined by LC-MS analyses) and other physiological characteristics have been studied in situ.

\section{MATERIAL AND METHODS}

Meteorology and hydrography. Meteorological data before the experiment were obtained from the Galician Meteorological Service (Meteogalicia). A conductivity-temperature-depth (CTD) Sea Bird Electronics Model 25 was used to obtain vertical profiles of temperature, salinity and fluorescence. From 9 to 10 November 2005, intensive sampling of the vertical distribution of physical parameters and cellular concentration of dinoflagellates was carried out aboard RV 'J. M. Navaz' at a fixed station (Bueu, P2, $42^{\circ} 21.40^{\prime} \mathrm{N}$, $8^{\circ} 46.42^{\prime}$ W) in Ría de Pontevedra (Fig. 1). Sampling was conducted from 17:00 h GMT on 9 November to 15:00 h on 10 November at $2 \mathrm{~h}$ intervals, except from 07:00 to 11:00 h on 10 November, when sampling was carried out every hour. Passive samplers to adsorb lipophilic toxins were deployed from 8 to 14 November.

Field sampling. Water samples to describe the vertical distribution of Dinophysis acuta and other dinoflagellates were collected from specific depths, chosen after real time readings of the CTD casts, with Niskin oceanographic bottles. Vertical hauls (one every $2 \mathrm{~h}$ ) with a $20 \mu \mathrm{m}$ mesh net were collected and passed through a $100 \mu \mathrm{m}$ mesh to eliminate large microzooplanktonic organisms. Three sub-samples were collected from each vertical haul for several purposes: (1) $15 \mathrm{ml}$ fixed with

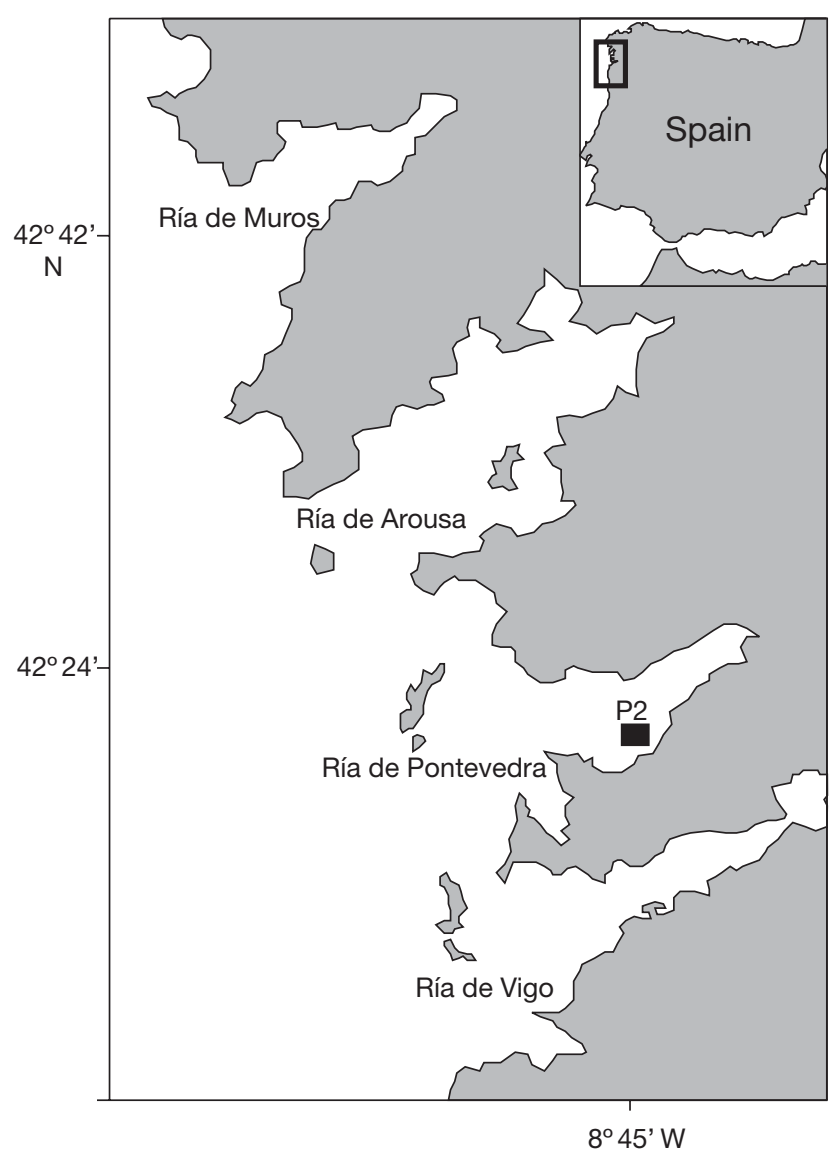

Fig. 1. Galician Rías Baixas (NW Spain) and location of the sampling point (P2) in Ria de Pontevedra

Lugol's iodine acid solution for cells counts; (2) $50 \mathrm{ml}$ fixed with formaldehyde to estimate in situ division rates according to Reguera et al. (2003); and (3) the plankton slurry obtained after concentration of the remaining material from the haul through a $20 \mu \mathrm{m}$ mesh collector, drained with the help of cellulose paper under the collector, was backwashed with a squirting bottle with methanol and immediately stored in a deep-freeze on board. Initial and final volumes of the concentrate were logged for further estimates of toxin content per cell. Back in the laboratory, the methanol-fixed samples were kept at $-20^{\circ} \mathrm{C}$ until time of analysis.

Lipophilic toxins dissolved in seawater were tracked with Diaion HP20 adsorbing resins as described by MacKenzie et al. (2004). Resin holders were made by mounting $77 \mu \mathrm{m}$ plankton mesh on a cylindrical PVC frame $(9.5 \mathrm{~cm}$ long, $2.5 \mathrm{~cm}$ diameter). They were filled with approximately $3 \mathrm{~g}$ (dry weight) of resin that had been washed with methanol and resuspended in $25 \mathrm{ml}$ of milliQ water for activation. They were then placed at 3,7 and $12 \mathrm{~m}$ depth (2 resin-holders per depth) on a rope hung by a mussel raft in the study area from 8 to 14 November 2005. 
After recovery of the resin holders from the seawater and extraction of the toxins, the resin was dried at room temperature and weighed to estimate possible losses of resin either during the dispensing process into the resin holders or while it was deployed in the field. To avoid problems of saturation, the amount of resin placed in the resin holders was empirically determined after calibrations in the laboratory with dissolved lipophilic toxins (OA, DTX1 and YTX) in the filtrate from Protoceratium reticulatum (Claparède \& Lachmann) Bütschli cultures enriched with extracts of Prorocentrum lima (Ehrenberg) Stein.

Phytoplankton counts. Phytoplankton from bottle samples was quantified by the Utermöhl method under a Nikon Eclipse TE2000-S inverted microscope after sedimentation from $25 \mathrm{ml}$ columns. The whole bottom of the sedimentation chamber was scanned at a magnification of $100 \times$ to count large (>20 $\mu \mathrm{m})$ cells (including Dinophysis spp.) and 1 or 2 transects along diameters at a magnification of $400 \times$ to count small $(<20 \mu \mathrm{m})$ cells. Vertical distributions of physical parameters and cell densities were plotted with the Origin and Surfer contour programmes. For quantification of cells in the net hauls (toxin samples), $3 \mathrm{ml}$ of lugol-fixed subsamples were placed in sedimentation chambers for $1 \mathrm{~h}$. Depending on cellular abundance, either one half of the bottom or the whole bottom of the chamber was scanned. Differential interference contrast (DIC) and epifluorescence (blue light filter) digitized micrographs of plankton concentrates were taken with a Nikon D70 camera coupled to the microscope.

A standardized Morisita index of dispersion $\left(I_{p}\right)$ (Krebs 1989) was used to estimate the aggregation of Dinophysis acuta cells. This index, with values that range from -1 to 1 , with $95 \%$ confidence intervals at +0.5 and -0.5 , is independent of population density and sample size $\left(I_{p}>0\right.$, aggregated pattern; $I_{p}=0$, random pattern; $I_{p}<0$ homogeneous distribution). Cell maxima observed between 0 and $1 \mathrm{~m}$ depth were not included in multiple regression analyses to relate aggregation with density gradients because CTD measurements in the top metre are not very accurate.

Cell size, vacuolation and starch granules. Maximum length (L) and width (W) of at least 50 micrographs of lugol-fixed cells of Dinophysis acuta were measured to estimate mean size at each sampling point. Micrographs were obtained with the camera-microscope system coupled to an image analyser programme (IPPlus Media Cybernetics). The cells' equivalent biovolume was estimated as described in Olenina et al. (2006). A minimum of 100 formaldehyde-fixed specimens were examined to estimate percentages of cells with digestive vacuoles that appear after mixotrophic behaviour (Park et al. 2006). We also examined 100 lugol-fixed specimens to estimate percentage of cells containing starch granules.
Division rate and intrinsic mortality. In situ division rates were estimated (based on morphological characters) from the frequency of dividing (paired) and recently divided (incomplete development of the left sulcal list) cells as described in Reguera et al. (2003), following the model of Carpenter \& Chang (1988):

$$
\mu=\frac{1}{n\left(T_{C}+T_{r}\right)} \sum_{i=1}^{n}\left(t_{s}\right)_{i} \ln \left[1+f_{C}\left(t_{i}\right)+f_{r}\left(t_{i}\right)\right]
$$

where $\mu$ is the daily average specific division rate, $f_{c}\left(t_{i}\right)$ is the fraction of cells in the cytokinetic cell phase (paired cells with incomplete development of the left sulcal lists), and $f_{r}\left(t_{i}\right)$ is the half-fraction of cells in the recently divided cell phase (missing the lower part of the left sulcal list) in the $i$ th sample. $T_{C}$ and $T_{r}$ are the duration of each of the previously defined cell phases respectively, $n$ is the number of samples taken in a $24 \mathrm{~h}$ sampling cycle, and $t_{s}$ is the sampling interval in hours. The model of Vaulot (1992), to estimate $\mu_{\min }$, was also applied:

$$
\mu_{\min }=\ln \frac{\left(1+f_{\max }\right)}{\left(1+f_{\min }\right)}
$$

where $f_{\max }$ and $f_{\min }$ are the maximum and minimum summed fractions of cells in the cytokinetic (paired) phase plus the recently divided cell phase observed at any time during the daily cycle.

A minimum of 1000 cells were observed for each sampling point. Frequencies (percentages) of dead cells $\left(f_{d}\right)$ were estimated as the ratio between empty individuals (no cellular content, $C_{d}$ ) plus half the number of empty thecae (Th), and the total number of cells $\left(C_{t}\right)$ in the same formalin-fixed samples, according to the equation:

$$
\mathrm{f}_{\mathrm{d}}=\frac{C_{d}+\frac{T h}{2}}{C_{t}}
$$

where $C_{n}$ are full cells, and $C_{t}=C_{d}+T h+C_{n}$.

Phytoplankton toxin extractions. Net samples resuspended in methanol were sonicated for $1 \mathrm{~min}$ and remains in the sonication probe were rinsed with $500 \mu \mathrm{l}$ of methanol. Extracts were centrifuged at $4620 \times g$ for $20 \mathrm{~min}$, the supernatant collected, and the pellet resuspended in $2 \mathrm{ml}$ for a second extraction repeating the same procedure. An aliquot from each washing step was injected into the LC-MS to control the efficiency of the extraction. Finally, the 2 supernatants were combined, mixed and the final volume logged. An aliquot of this solution was filtered through a $0.45 \mu \mathrm{m}$ nylon filter (Gelman Nylon Acrodisc $13 \mathrm{~mm}$ or Osmonic Cameo $3 \mathrm{~N} 3 \mathrm{~mm}$ ) prior to injection into the LC-MS system; the aliquot volume varied ( 2 to $10 \mu \mathrm{l}$ ) depending on the kind of toxin being analyzed and the cellular concentration of Dinophysis in the sample.

Extraction of toxins from the resins. Extraction of toxins from the resins was carried out following 
MacKenzie et al. (2004), with some modifications. Once the resin holders were recovered, the resins from each resin-holder were poured into a small $(50 \mathrm{ml})$ plastic cylindrical collector with an end covered with a 20- $\mu \mathrm{m}$ mesh, and washed with $\sim 40 \mathrm{ml}$ milliQ water to eliminate sea salts. After drainage, the resin was collected from the mesh and transferred to a $50 \mathrm{ml}$ syringe-like elution cylinder with a clamped silicon tube (with a cotton filter for retaining the resin) attached to its narrow end; $20 \mathrm{ml}$ of methanol were then poured on top of the resin and left a minimum of $2 \mathrm{~h}$ before elution of the methanol. The resin was then washed with $10 \mathrm{ml}$ of methanol at a time (flow of $0.5 \mathrm{ml} \mathrm{min}{ }^{-1}$ ) until a final volume of $50 \mathrm{ml}$ was obtained. These methanol fractions were kept at $-20^{\circ} \mathrm{C}$ until analysis. In the case of samples that were not analyzed immediately, the resins, after being washed with milliQ water, were transferred to a $20 \mathrm{ml}$ glass vial with $15 \mathrm{ml}$ of methanol and kept at $4{ }^{\circ} \mathrm{C}$ in the dark until elution time.

The toxin extracts were dried at $40^{\circ} \mathrm{C}$ under reduced pressure on a Speed Vac (Savant Instruments), resuspended in $500 \mu$ l of methanol and filtered through $0.45 \mu \mathrm{m}$ filters (Gelman Nylon Acrodisc $13 \mathrm{~mm}$ or Osmonic Cameo 3N $3 \mathrm{~mm}$ ) prior to injection of $20 \mu \mathrm{l}$ sub-samples into the LC-MS system.

LC-MS analyses. Chromatographic separation was performed on a Waters XTerra C18 column $(2.1 \times$ $150 \mathrm{~mm}$ ) with $5 \mu \mathrm{m}$-particle packing. The mobile phase consisted of (A) $2 \mathrm{mM}$ ammonium acetate at pH 5.8 and (B) $100 \%$ methanol, with a flow rate of $0.2 \mathrm{ml} \mathrm{min}^{-1}$. A linear gradient elution from 60 to $100 \%$ $\mathrm{B}$ was run between 0 and $20 \mathrm{~min}$ and held at $100 \% \mathrm{~B}$ for 2 min, then decreased to $60 \%$ B over 3 min and held at $60 \%$ for $5 \mathrm{~min}$.

LC-MS analyses were performed on a liquid chromatograph (Thermo Finnigan Surveyor) coupled to a mass spectrometer (Thermo Finnigan LCQ-Advantage) equipped with ion trap and micro-electrospray ionization interface (micro ESI). During the analyses, between 30 and $50 \mu \mathrm{l}$ of the LC eluent were introduced into an Ion-Spray interface through the microcapillary. The mass spectrometer was operated with a temperature of the heated capillary of $250^{\circ} \mathrm{C}$ and a spray voltage of 3.0 and $4.5 \mathrm{kV}$, a flow of $20 \mathrm{ml} \mathrm{min}^{-1}$ for the sheath gas and of $10 \mathrm{ml} \mathrm{min}{ }^{-1}$ for the auxiliary gas.

Full scan data were acquired from specific mass to charge ratio (m/z) 300 to 2000 , in both negative and positive ionization modes. Negative mode was performed to confirm the toxin spectra. The selected ion monitoring (SIM) was performed on ion $\mathrm{m} / \mathrm{z} 805$ $[\mathrm{M}+\mathrm{H}]^{+}, 822\left[\mathrm{M}+\mathrm{NH}_{4}\right]^{+}, 827[\mathrm{M}+\mathrm{Na}]^{+}$and $803[\mathrm{M}-\mathrm{H}]^{-}$ for OA and DTX2; $876\left[\mathrm{M}+\mathrm{NH}_{4}\right]^{+}, 881[\mathrm{M}+\mathrm{Na}]^{+}, 857$

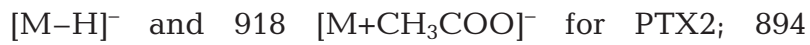
$\left[\mathrm{M}+\mathrm{NH}_{4}\right]^{+}, 899[\mathrm{M}+\mathrm{Na}]^{+}$and $875[\mathrm{M}-\mathrm{H}]^{-}$for PTX2SA; $836\left[\mathrm{M}+\mathrm{NH}_{4}\right]^{+}, 841[\mathrm{M}+\mathrm{Na}]^{+}$and $817[\mathrm{M}-\mathrm{H}]^{-}$for DTX1; and $892\left[\mathrm{M}+\mathrm{NH}_{4}\right]^{+}, 897[\mathrm{M}+\mathrm{Na}]^{+}$and $874[\mathrm{M}-\mathrm{H}]^{-}$for PTX1. OA-D8 was detected on ion $\mathrm{m} / \mathrm{z} 946\left[\mathrm{M}+\mathrm{NH}_{4}\right]^{+}$, $951[\mathrm{M}+\mathrm{Na}]^{+}$and $988\left[\mathrm{M}+\mathrm{CH}_{3} \mathrm{COO}\right]^{-}$.

To search for the presence of sulphated forms of dinophysistoxin-4 (DTX4) and dinophysistoxin-5b (DTX5b), derived from OA-D8, $\mathrm{m} / \mathrm{z}$ for our adduct ions were calculated from Hu et al. (1995a) and Paz et al. (2007). We also sought the presence of OA diol-esters with $\mathrm{C} 7$ and $\mathrm{C} 9$ side chain, whose $\mathrm{m} / \mathrm{z}$ were calculated for our adduct ions from Suzuki et al. (2004).

OA and pectenotoxin-2 (PTX2) certified reference standards (NRC, Canada) were used for calibration of the LC-MS and quantification of toxins. Quantified DTX2 $\left(6 \mu \mathrm{g} \mathrm{ml}^{-1}\right)$, PTX2 seco acid (PTX2SA) (1 $\mu \mathrm{g}$ $\left.\mathrm{ml}^{-1}\right)$, DTX1 $\left(1 \mathrm{\mu g} \mathrm{ml}^{-1}\right)$ and PTX1 $\left(10 \mu \mathrm{g} \mathrm{ml}^{-1}\right)$ reference materials were provided by colleagues (see 'Acknowledgements'). Qualitative reference material of OA-D8 diol-ester (OA-D8) was prepared from cultures of Prorocentrum lima (Paz et al. 2007).

A Waters XBridge column was used to confirm the presence of OA-D8 in the secondary standard and in the samples. Thus, the peaks corresponding to OA-D8 were identified in the earlier LC-MS chromatograms run with phytoplankton extracts, from which the toxins were separated with the XTerra column. OA calibration curves were used to estimate, as OA equivalents, the diol-esters.

A working solution $\left(\sim 0.6 \mathrm{ng} \mathrm{pl}^{-1}\right)$ of OA, DTX2 and PTX2 was used to generate a 4-point calibration curve every 15 to 20 samples with variable injection volumes. The linearity of each point of the calibration curve was tested following Van Trijp \& Roos (1991). Another working solution with PTX2SA, PTX1 and DTX1 $\left(\sim 0.3 \mathrm{ng} \mathrm{pl}^{-1}\right)$ was also used. With the accepted linearity points, calibration lines were obtained for each toxin depending on concentration in the samples. The range for OA and DTX2 (ions at $\mathrm{m} / \mathrm{z} 805$ plus 822 and 827) was from 1.5 to $6.0 \mathrm{ng}\left(Y=0.1517 x, \mathrm{r}^{2}=0.9984\right.$; $Y=0.1994 x, r^{2}=0.9862$, respectively) and for PTX2 (ions at $\mathrm{m} / \mathrm{z} 876$ plus 881) from 1.8 to $7.0 \mathrm{ng}$ ( $Y=$ $0.5173 x, r^{2}=0.9997$ ). In the case of PTX2SA (ions at $\mathrm{m} / \mathrm{z} 894$ plus 899), PTX1 (ions at $\mathrm{m} / \mathrm{z} 892$ plus 897) and DTX1, (ions at $\mathrm{m} / \mathrm{z} 841$ ), ranges from 0.5 to $3.0 \mathrm{ng}$ were detected $\left(Y=2.8781 x, \mathrm{r}^{2}=0.9807 ; Y=2.0982 \mathrm{x}, \mathrm{r}^{2}=\right.$ 0.9896; $Y=2.8681 x, \mathrm{r}^{2}=0.9590$, respectively).

Rate of toxin accumulation per cell. The in situ variability of the cell toxin quota through the daily cycle was estimated with the following equations:

$$
\begin{gathered}
Q_{t_{2}}=Q_{t_{1}} \mathrm{e}^{\mu_{\mathrm{t}}\left(t_{2}-t_{1}\right)} \\
\mu_{\mathrm{t}}=\frac{\ln Q_{t_{2}}-\ln Q_{t_{1}}}{\left(t_{2}-t_{1}\right)}
\end{gathered}
$$

where $Q_{t_{2}}=$ cell toxin quota at hour $t_{2} ; Q_{t_{1}}=$ cell toxin quota at hour $t_{1} ; \mu_{\mathrm{t}}=$ toxin accumulation rate $\left(\mathrm{h}^{-1}\right)$. 


\section{RESULTS}

\section{Hydrography and vertical distribution of Dinophysis acuta}

Hydrographic characteristics during the cruise corresponded to the typical autumn conditions that follow the end of the upwelling season and marked freshwater input. Vertical profiles revealed a thermal inversion (surface water $0.9^{\circ} \mathrm{C}$ colder than water at $9 \mathrm{~m}$ depth), and a salinity-driven stratification (32.78 psu at the surface, $34.37 \mathrm{psu}$ at $4 \mathrm{~m}$ at low tide) (Fig. 2A); this feature was partially eroded towards the end of the cruise after the onset of northerly (upwelling-promoting) winds. High cell concentrations of Dinophysis acuta appeared mainly within the colder and more brackish water at the 1 to $4 \mathrm{~m}$ depth during the whole sampling period. Vertical distribution of cell maxima reflected those of the density gradients. Fig. 2B shows a vertical profile of water density and $D$. acuta numbers at 19:00 h, when the maximum cell concentration (19360 cells $\mathrm{l}^{-1}$ ) was detected. The maximum was located at $2 \mathrm{~m}$, the same depth where the density gradient $\left(0.77 \mathrm{~m}^{-1}\right.$ between 1 and $3 \mathrm{~m}$ ) was highest. Diel vertical migration of $D$. acuta was not observed during the study period, but discontinuities (peaks) in cell density dis- tribution were more marked when density gradients were higher (Fig. 2B, 19:00 h), although less dense aggregations appeared associated with weaker density gradients, such as those observed at 05:00 h and 09:00 h.

Standardized Morisita index values $\left(I_{p}\right)$, all higher than 1, indicated different levels of Dinophysis acuta aggregation through time. Highest values of $I_{p}$ were observed during low and rising tide, although the relationship (second order polynomial fit) between $I_{p}$ and tidal level was not statistically significant. However, the cell maximum in each sampling hour $(\mathrm{n}=9)$ was significantly related (multiple regression analyses, $\mathrm{p}<$ $0.05, r^{2}=0.76$ ) with both the tidal levels $(p<0.05$, $\left.r_{\text {partial }}=-0.76\right)$ and density gradients $(p<0.05$, $\left.\mathrm{r}_{\text {partial }}=0.77\right)$.

\section{Net phytoplankton}

Dinoflagellates represented more than $93 \%$ of the total microplankton assemblage during the whole study period (Table 1). Dinophysis acuta, Ceratium furca (Ehrenberg) Claparède \& Lachmann, Ceratium fusus (Ehrenberg) Dujardin, and the paralytic shellfish poison (PSP) toxin producer Gymnodinium catenatum represented 81 to $97 \%$ of the total phytoplankton; the

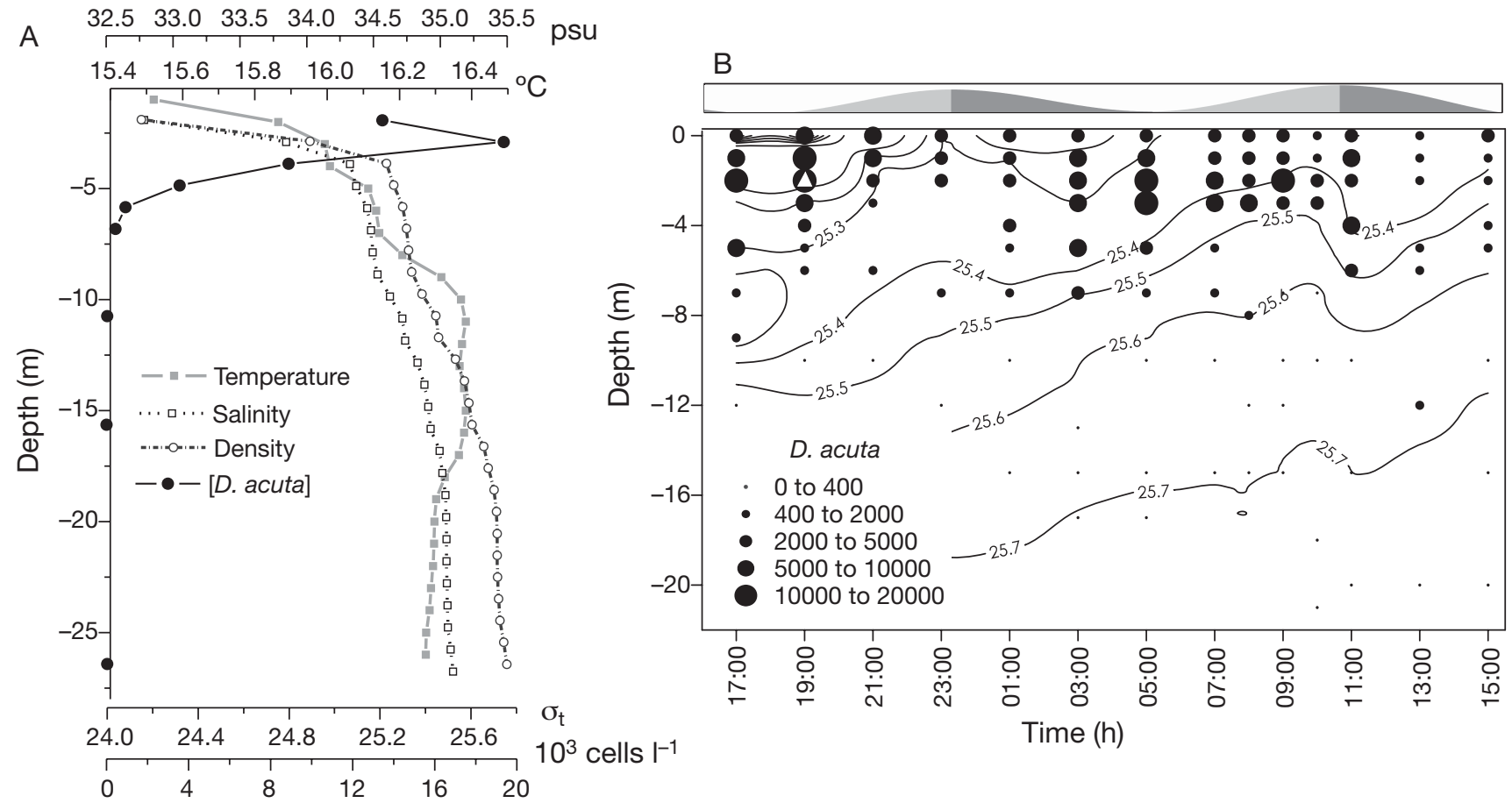

Fig. 2. Dinophysis acuta. (A) Concentration (cells $\mathrm{l}^{-1}$ ), as well as vertical distribution of salinity (psu), temperature $\left({ }^{\circ} \mathrm{C}\right)$ and density $\left(\sigma_{\mathrm{t}}\right.$, sigma-t) at Stn P2 (Ría de Pontevedra), at 19:00 h GMT on 9 October 1997. (B) Concentration (cells ${ }^{-1}$ ) and vertical distribution of density $\left(\sigma_{\mathrm{t}}\right.$, sigma-t) at the same station from 9 to 10 November 2005. The maximum concentration recorded (19370 cells $\mathbf{l}^{-1}$ ) is marked with a triangle. State of the tide is indicated on the horizontal bar above 
Table 1. Percentage of phytoplanktonic species in $20 \mu \mathrm{m}$ vertical net-haul samples, collected for toxin analyses during the daily cycle on 9 and 10 November 2005

\begin{tabular}{|c|c|c|c|c|c|c|c|c|c|c|c|c|c|c|}
\hline & \multicolumn{14}{|c|}{ Sampling hour } \\
\hline & 17 & 19 & 21 & 23 & 1 & 3 & 5 & 8 & 9 & 10 & 11 & 12 & 13 & 15 \\
\hline Total diatoms & 1 & $\mathbf{0}$ & $\mathbf{0}$ & 1 & 1 & 1 & 1 & $\mathbf{0}$ & 7 & 2 & 3 & 6 & 7 & 3 \\
\hline \multicolumn{15}{|l|}{ Dinophysis sp. } \\
\hline D. acuminata & 0.1 & 0.3 & 0.1 & 0 & 0 & 0 & 0 & 0 & 0.1 & 0 & 0.1 & 0 & 0 & 0.3 \\
\hline D. acuta & 50 & 48 & 51 & 38 & 47 & 43 & 51 & 46 & 54 & 53 & 41 & 36 & 33 & 37 \\
\hline D. caudata & 0.2 & 0 & 1 & 0 & 1 & 0 & 0 & 0 & 0 & 1 & 0 & 0 & 0 & 0 \\
\hline D. dens & 0.4 & 1 & 0 & 0 & 1 & 0 & 1 & 0 & 0 & 1 & 1 & 1 & 1 & 1 \\
\hline D. diegensis & 0 & 0 & 0 & 0 & 0 & 0 & 0 & 0.1 & 0 & 0 & 0 & 0 & 0 & 0 \\
\hline D. odiosa & 0 & 0 & 0 & 0 & 0 & 0 & 0 & 0 & 0 & 0 & 0 & 0.1 & 0 & 0 \\
\hline D. rotundata & 0.2 & 0 & 0 & 0 & 0 & 0 & 0 & 0 & 0 & 1 & 0 & 1 & 1 & 1 \\
\hline Total & 51 & 49 & 52 & 39 & 49 & 43 & 52 & 46 & 54 & 56 & 42 & 38 & 35 & 39 \\
\hline \multicolumn{15}{|l|}{ Protoperidinium sp. } \\
\hline P. crassipes & 0 & 0 & 0 & 0 & 1 & 0 & 0 & 1 & 0 & 1 & 1 & 0 & 1 & 1 \\
\hline P. diabolus & 0 & 0 & 0 & 1 & 0 & 0 & 0 & 0 & 0 & 0 & 0 & 0 & 0 & 0 \\
\hline P. divergens & 1 & 2 & 1 & 2 & 8 & 4 & 4 & 4 & 4 & 3 & 4 & 5 & 6 & 0 \\
\hline P. brochii & 0 & 0 & 0 & 0 & 0 & 0 & 0 & 0 & 0 & 0 & 0 & 0 & 1 & 0 \\
\hline P. steinii & 0 & 0 & 0 & 0 & 1 & 0 & 1 & 1 & 1 & 1 & 1 & 2 & 0 & 1 \\
\hline Protoperidinium spp. & 0 & 0 & 0 & 0 & 0 & 0 & 0 & 0 & 0 & 0 & 0 & 0 & 1 & 1 \\
\hline Total & 1 & 2 & 1 & 3 & 9 & 4 & 5 & 6 & 5 & 5 & 6 & 7 & 9 & 3 \\
\hline \multicolumn{15}{|l|}{ Other dinoflagellates } \\
\hline Ceratium furca & 3 & 1 & 1 & 4 & 3 & 2 & 5 & 6 & 6 & 6 & 7 & 6 & 11 & 18 \\
\hline Ceratium fusus & 19 & 25 & 34 & 27 & 27 & 33 & 29 & 22 & 12 & 23 & 30 & 38 & 34 & 31 \\
\hline Gymnodinium catenatum & 23 & 20 & 10 & 25 & 9 & 16 & 7 & 18 & 14 & 7 & 11 & 3 & 4 & 3 \\
\hline Dinoflagellate spp. & 2 & 2 & 1 & 1 & 1 & 0 & 1 & 1 & 1 & 2 & 1 & 2 & 2 & 2 \\
\hline Total & 47 & 48 & 46 & 57 & 40 & 51 & 42 & 47 & 33 & 38 & 49 & 49 & 51 & 54 \\
\hline
\end{tabular}

remainder was composed of diatoms. D. acuta represented between 97.4 and $100 \%$ of the microalgae known to contain DSP toxins (i.e. the species belonging to the genus Dinophysis) and was the numerically dominant species in all net hauls except one. The density of $D$. acuta in these plankton concentrates ranged from 218 to 1510 cells $\mathrm{ml}^{-1}$.

\section{Cell size and frequency of vacuolated and starch-containing cells}

Changes in cellular volume of Dinophysis acuta cells were not statistically significant $(46801 \pm 11776$ to $53722 \pm$ $10363 \mu \mathrm{m}^{3} ; \mathrm{n} \geq 50$ ) (means $\pm \mathrm{SD}$ ) (Fig. 3) ( $p<0.05$, test of Tukey and Bonferroni). Cells of $D$. acuta filled with digestives vacuoles were practically undetectable (Fig. 3). Only in the samples from 01:00 and 07:00 h did some of the cells $(1 \%)$ have vacuoles. In contrast, the frequency of cells with starch granules was very high in all samples except one. Frequencies decreased from $93 \%$ at $17: 00 \mathrm{~h}$ to $51 \%$ at $09: 00 \mathrm{~h}$ and remained above $80 \%$ from 10:00 h until the end of the sampling.
Some cells of Dinophysis acuta showed no autofluorescence at all but most of them showed the typical Dinophysis orange autofluorescence associated with their cryptophycean-like phycoerythin pigmentation (Fig. 4). Within the orange autofluorescent cells, great variability in auto-fluorescence intensity was observed: some cells had a very bright orange colour whereas others exhibited more moderate autofluorescence.

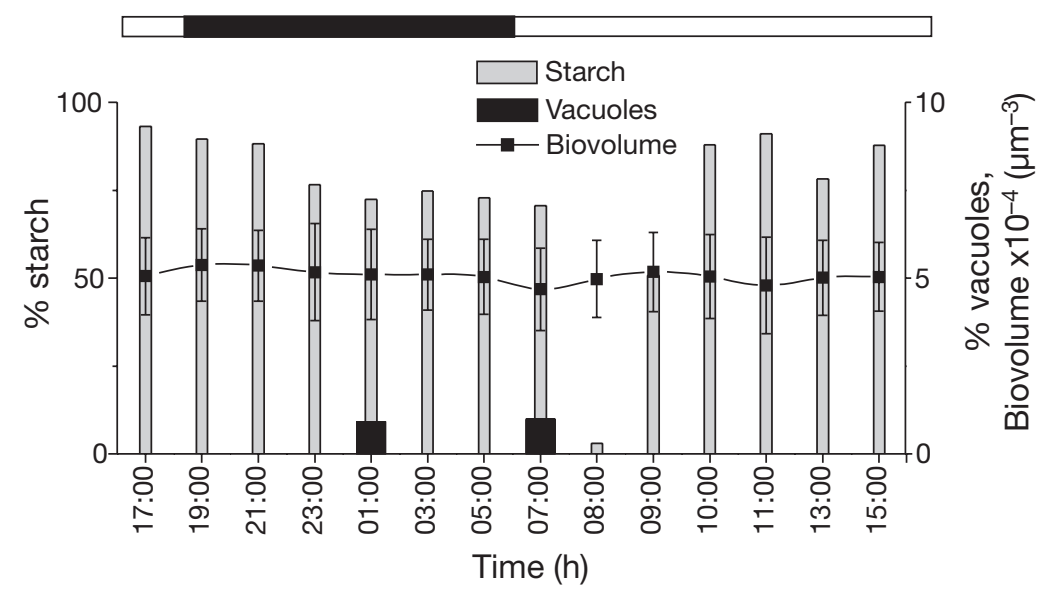

Fig. 3. Dinophysis acuta. Diel variability in percentage of vacuolated cells and cells with starch granules, and biovolume $\left(\mu^{3}{ }^{3}\right.$, mean $\left.\pm S D\right)$ 


\section{Division rate and mortality}

Maximum frequencies of dividing cells (pairs attached by the dorsal margin) and recently divided cells (one half of those with incomplete development of the left sulcal list) were extremely low $(0.16 \%$ and $2.27 \%$, respectively), and both were detected at 10:00 h (Fig. 5A). The maximum frequency of dividing cells was much lower than the maximum frequency of recently divided cells. The frequency of dead cells (cells with no cellular content plus one half of empty thecae) ranged from 0.2 to $14.7 \%$, with the maximum value observed at $15: 00 \mathrm{~h}$ on 10 November, towards the end of the cruise. The estimate of $\mu$, according to Eq. (1), was $0.024 \mathrm{~d}^{-1}$; the estimate of $\mu_{\text {min }}$, according to Eq. (2), was $0.030 \mathrm{~d}^{-1}$. Frequencies of dead cells, which increased from 2 to $15 \%$ between 09:00 and 15:00 h, were always much higher than total frequency of division (Fig. 5B). Therefore, from the point of view of intrinsic growth, division rate was almost zero, losses were higher than gains and hence the net growth was negative.

\section{LC-MS analyses}

Calibration curves were obtained for OA, DTX2 and PTX2 toxins, previously reported as the predominant toxins in phytoplankton samples rich in Dinophysis acuta in the Galician Rías Baixas (Fernández et al. 2006). Peaks corresponding to OA, DTX2, PTX2 and OA-D8 (at 5.99, 6.77, 11.75 and $14.21 \mathrm{~min}$, respectively) (Fig. 6), pre- sented spectra with $[\mathrm{M}+\mathrm{H}]^{+},\left[\mathrm{M}+\mathrm{NH}_{4}\right]^{+}$and $[\mathrm{M}+\mathrm{Na}]^{+}$ ions at $\mathrm{m} / \mathrm{z} 805,822$ and 827 for OA and DTX2; $\left[\mathrm{M}+\mathrm{NH}_{4}\right]^{+}$and $[\mathrm{M}+\mathrm{Na}]^{+}$ions at $\mathrm{m} / \mathrm{z} 876$ and 881 for PTX2 and 946 and 951 for OA-D8. The efficiency of toxin extraction (OA, DTX2 and PTX2) from the phytoplankton samples ranged between 95 and $98 \%$.

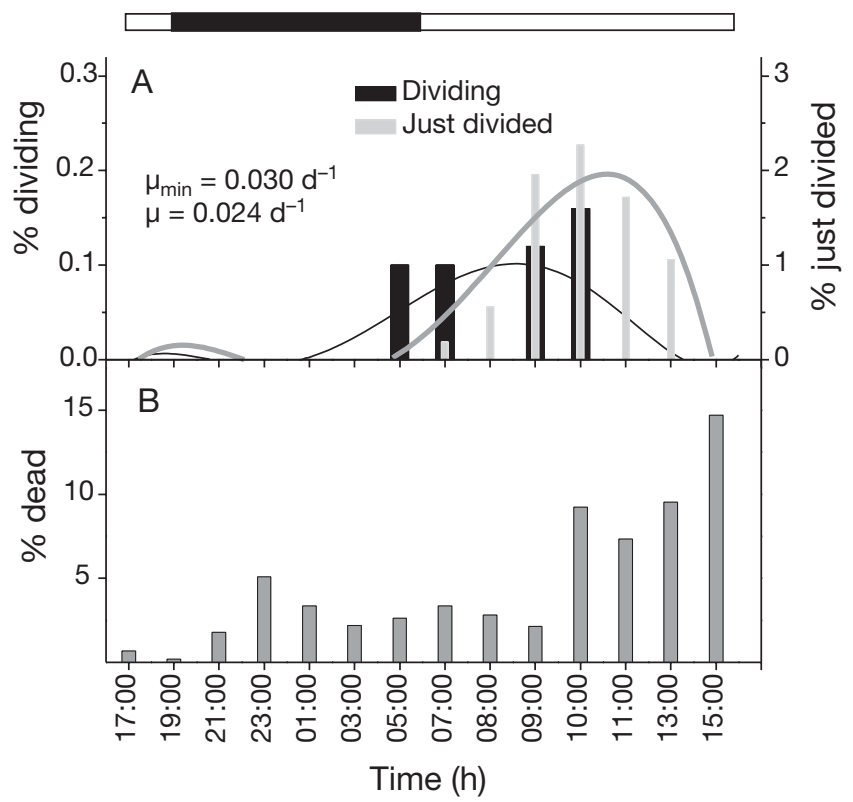

Fig. 5. Dinophysis acuta. (A) Diel distribution from 9 to 10 November 2005 of frequencies of paired (dividing) cells and recently divided cells fitted to a 5th degree polynomial curve.

(B) Diel distribution of frequencies of dead (lysed) cell. Horizontal bar on top indicates the light and dark hours
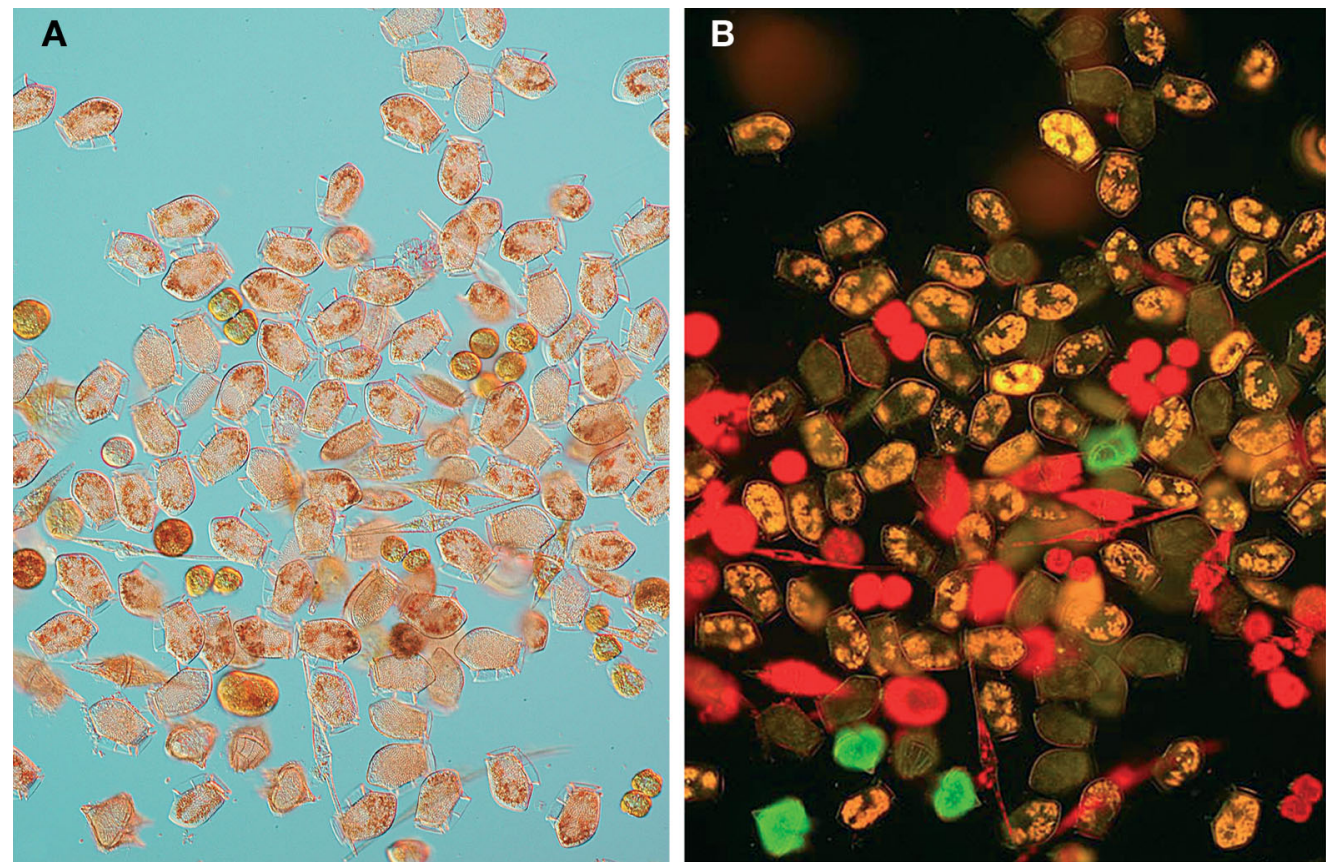

Fig. 4. Live cells of Dinophysis acuta. (A) Differential interference contrast (DIC) and (B) epifluorescence (blue light) micrographs of concentrated plankton samples $(40-100 \mu \mathrm{m}$ size fraction) collected at Stn P2 on 8 November 2005 

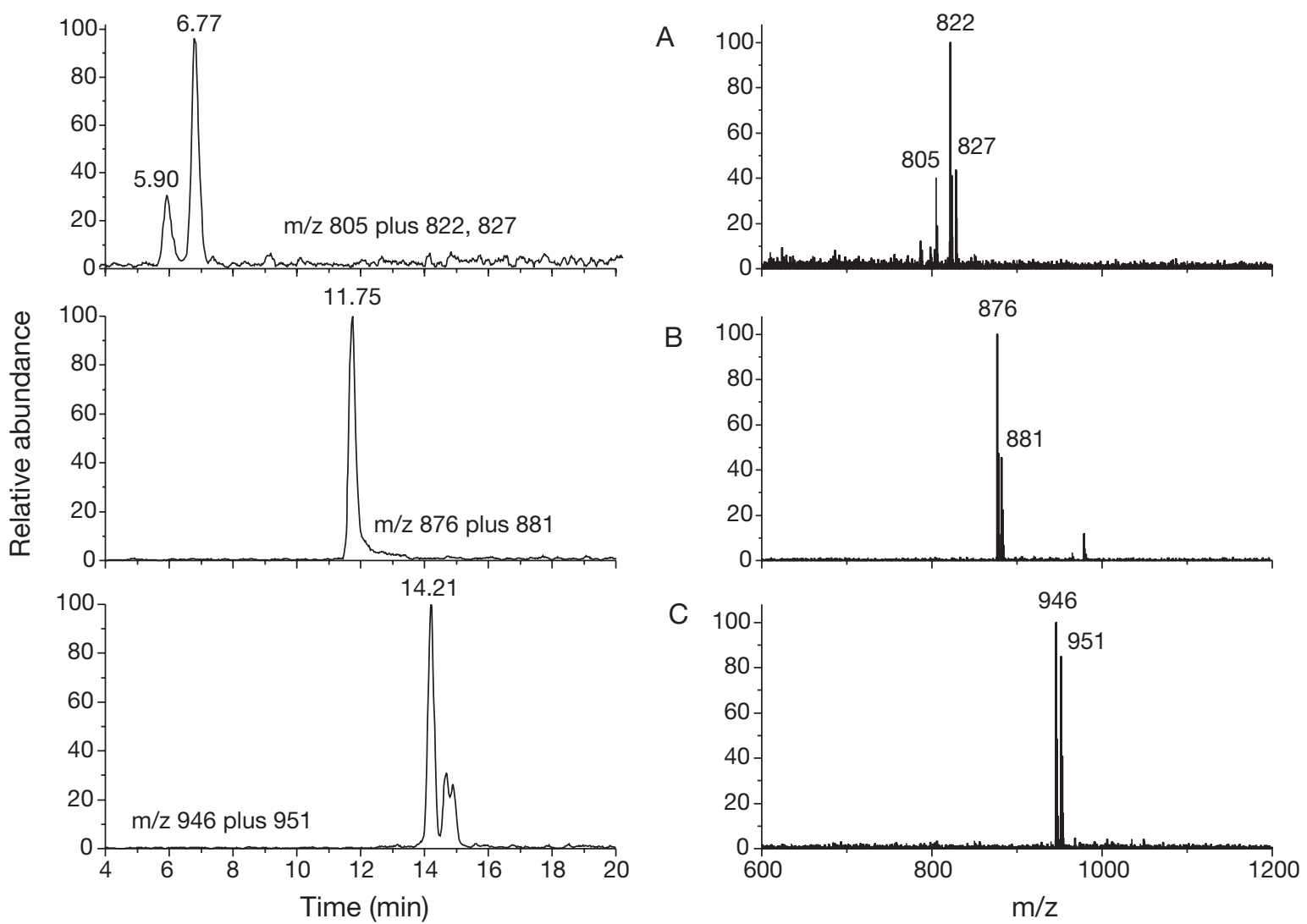

Fig. 6. LC-MS chromatograms, in positive ionization mode, of OA, DTX2, PTX2 standards and OA-D8 reference material, with their retention time (left) and mass spectra for $[\mathrm{M}+\mathrm{NH} 4]+$ and $[\mathrm{M}+\mathrm{Na}]+$ (right): (A) OA and DTX2, (B) PTX2, (C) OA-D8

\section{Toxin profile and cell toxin quota}

Analyses of net-haul extracts during this study, where Dinophysis acuta was the overwhelmingly dominant Dinophysis spp. (>96\%), presented a dominance of OA (26 to 51\%), DTX2 (23 to $34 \%$ ) and PTX2 (15 to 46\%), followed by OA-diol esters (OA-D8) (0.4 to $2.0 \%$ ). The OA:DTX2 ratio $(3: 2)$ (Fig. 7), was fairly constant the whole day ( $p<$ $0.0001, \mathrm{r}^{2}=0.89$ ), but that was not the case with the ratio between free forms of OA and PTX2, which ratio was variable and did not show any significant correlation. DTX1, PTX1 and PTX2SA were not detected in any of the phytoplankton samples. OA-D8 (retention time, RT $14.2 \mathrm{~min}$ ), presented a spectrum with $\left[\mathrm{M}+\mathrm{NH}_{4}\right]^{+}$and $[\mathrm{M}+\mathrm{Na}]^{+}$ions at $\mathrm{m} / \mathrm{z} 946$ and 951, respectively (Fig. 8). PTX2SA, PTX1 and DTX1 standards were detected at 8.2, 9.3 and $10.6 \mathrm{~min}$, respectively (Fig. 9). These retention times and mass spectra were the same as those used to estimate toxins adsorbed by the resins.

Fig. 10A,B shows the daily variation in cell toxin quota of okadaiates and PTX2 in Dinophysis acuta. Maximum cell toxin quota (95 pg of free okadaiates

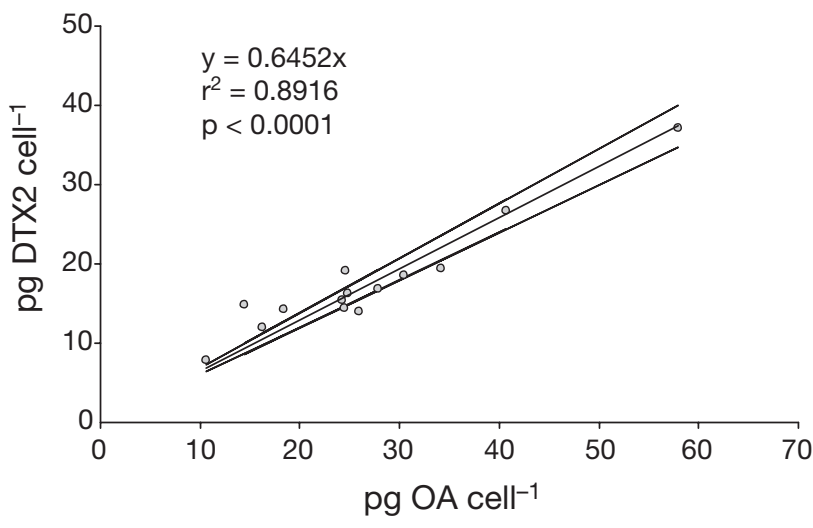

Fig. 7. Content of DTX2 versus OA throughout the cell cycle. The ratio is shown with $95 \%$ confidence intervals

and $38 \mathrm{pg}$ of PTX2) was observed during the night. The maximum cell toxin quota of all toxins, except OA-D8, was detected at 01:00 h. An increase in cell toxin quota of OA-D8 (to $1.4 \mathrm{pg} \mathrm{cell}^{-1}$ ) was observed at 03:00 h (Fig. 10C), but the maximum value $\left(1.6 \mathrm{pg} \mathrm{cell}^{-1}\right)$ was observed at 17:00 $\mathrm{h}$ (at the beginning of the cycle study). Highest increases in OA-D8 cell quota, such as 
those observed at 17:00 and 03:00 h, coincided with or followed a rise in OA concentrations. Neither DTX4 and DTX5b-like sulphated esters nor diol-esters of OA with $\mathrm{C} 7$ and $\mathrm{C} 9$ side chains were detected in the toxin extracts.

Positive values of $\mu_{\mathrm{t}}$ for OA+DTX2 were observed at 21:00, 01:00, 08:00, 10:00 and 13:00 h, while a negative rate was observed at 05:00 h (Fig. 11). Highest positive values of $\mu_{\mathrm{t}}$ for OA-D8 were always observed coinciding with a peak of OA+DTX2 (at 01:00 and 08:00 h). PTX2 accumulation rates showed a polymodal pattern, with increases at 21:00, 01:00, 07:00, 10:00, 15:00 $\mathrm{h}$ and decreases at 23:00, 05:00 and 08:00 h. No relationship was found between cell toxin quota and aggregation $\left(I_{p}\right)$.

\section{Dissolved toxins}

A large amount of dissolved toxins, compared with observations from previous weeks (authors' unpubl. data), was collected in the adsorbing resins held in the study area from 8 to 14 November 2005. Maximum adsorption of toxins - $6.0 \mu \mathrm{g}$ OA, $3.4 \mu \mathrm{g}$ DTX2, $2.5 \mu \mathrm{g}$ PTX2 and 1.5 PTX2SA per resin-holder - took place at a depth of $3 \mathrm{~m}$ (Fig. 12). Neither OA-D8 nor DTX1 were detected in the resins. A peak with similar RT (9.5 $\mathrm{min}$ ) and equal $\mathrm{m} / \mathrm{z}$ (897) to those of the PTX1 standard (Fig. 9) was detected in trace amounts $(0.1 \mu \mathrm{g}$ per resin-holder) only at $3 \mathrm{~m}$ depth.

\section{DISCUSSION}

\section{Behaviour and physiological characteristics of Dinophysis acuta during the cell cycle}

The population of Dinophysis acuta studied in this daily cycle had been recorded in low concentrations $\left(<100\right.$ cell $\left.1^{-1}\right)$ in the Galician Rías since early August. From then until the end of October, it showed a decreasing trend in intrinsic division rate $\left(\mu_{\min } 0.30\right.$ to 0.11 ) inversely proportional to an increasing trend in net growth rate, which reached a maximum at the end of October (Escalera et al. 2006a). Thus, the intensive sampling described here coincided with the annual
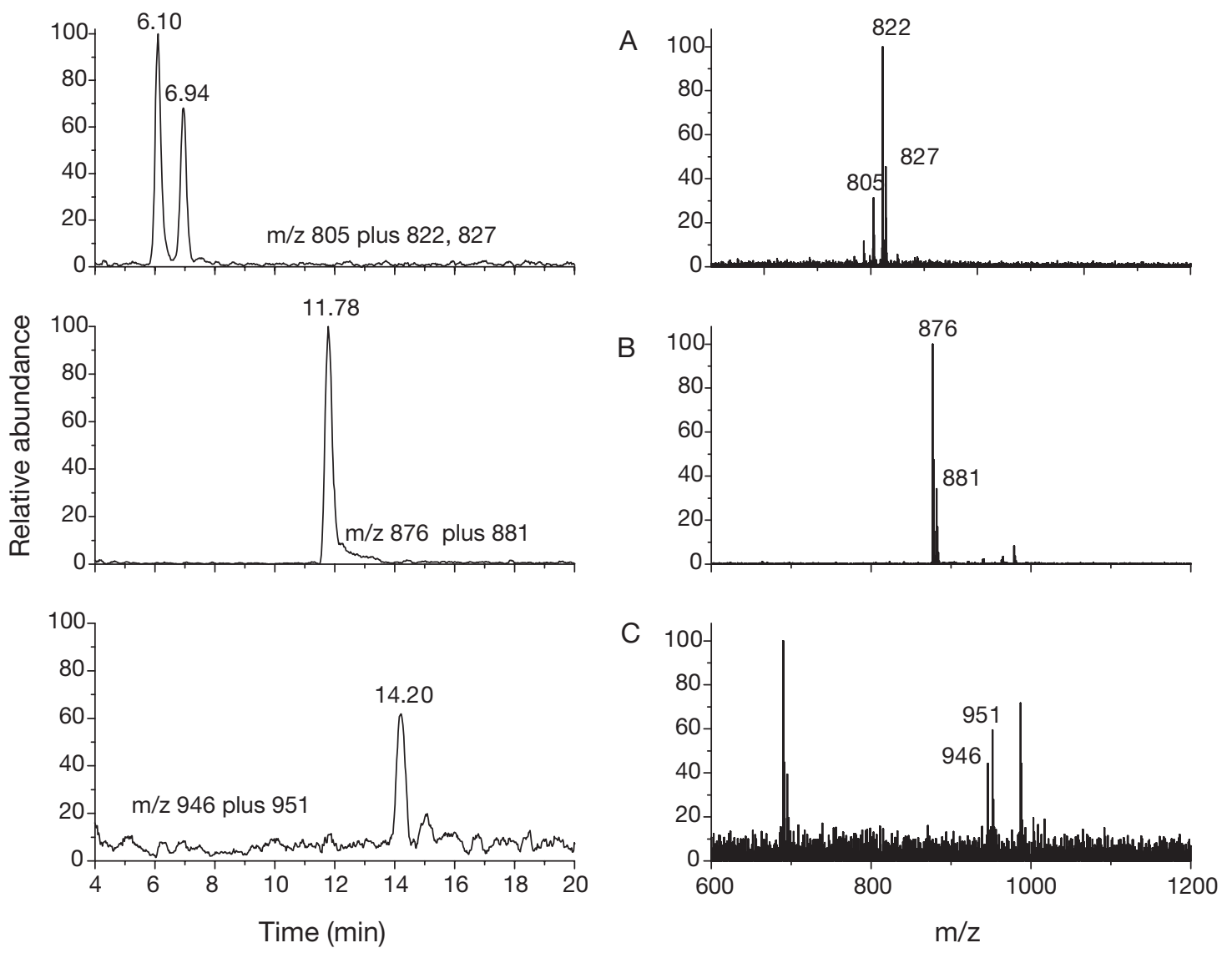

Fig. 8. Selected LC-MS chromatograms of a sample from 21:00 h GMT, in positive ionization mode of OA, DTX2, PTX2 and OA-D8 with their retention times (left) and respective mass spectra (right): (A) OA (mass spectral was identical for DTX2),

(B) PTX2, (C) OA-D8 

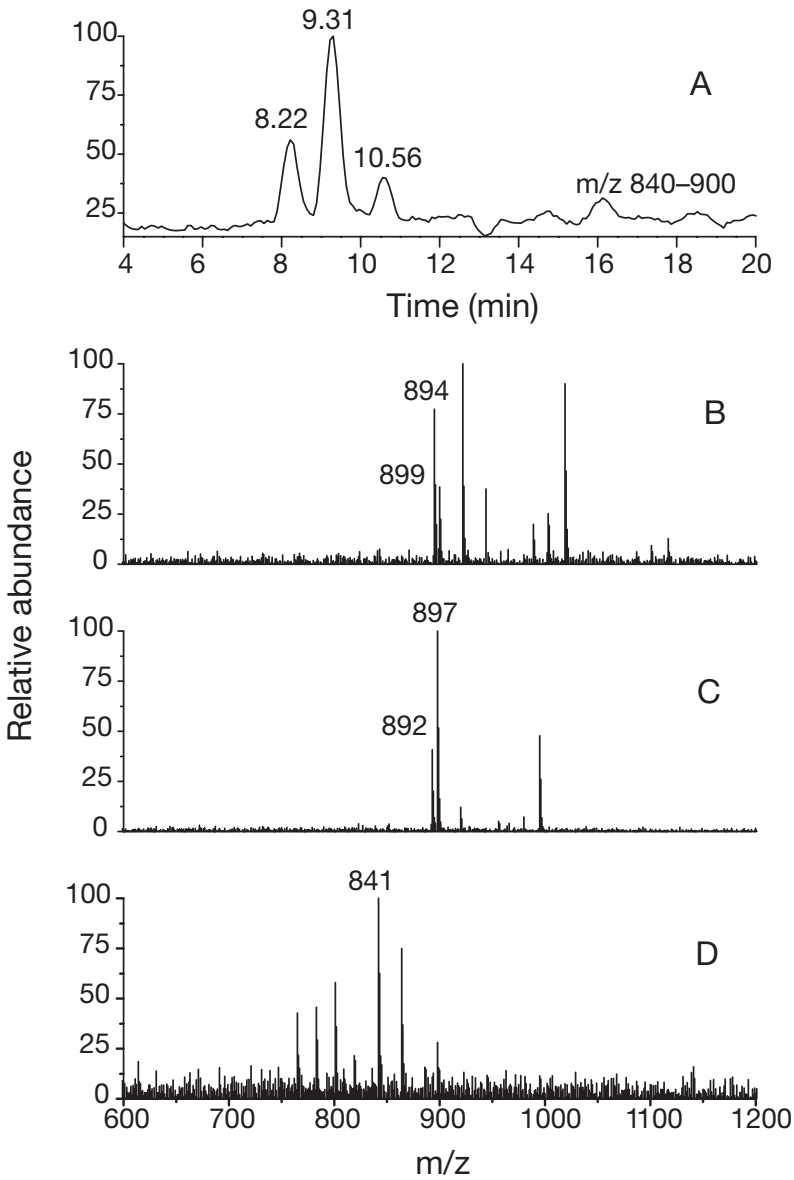

Fig. 9. (A) LC-MS chromatograms of standards in positive ionization mode: PTX2SA (RT $8.22 \mathrm{~min})$, PTX1 (RT $9.31 \mathrm{~min}$ ), DTX1 (RT $10.56 \mathrm{~min}$ ). Mass spectra are shown for (B) PTX2SA (m/z at 894 and 899), (C) PTX1 (m/z at 892 and 897), (D) DTX1 $(\mathrm{m} / \mathrm{z}$ 841)

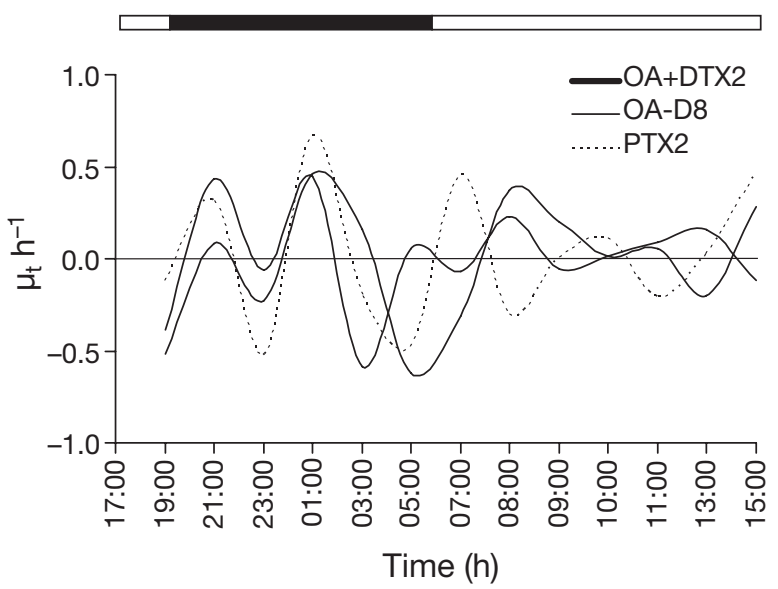

Fig. 11. Accumulation rate of cell toxin quota $\left(\mu_{t} h^{-1}\right)$ for OA+ DTX2, PTX2 and OA-D8 during the daily cycle

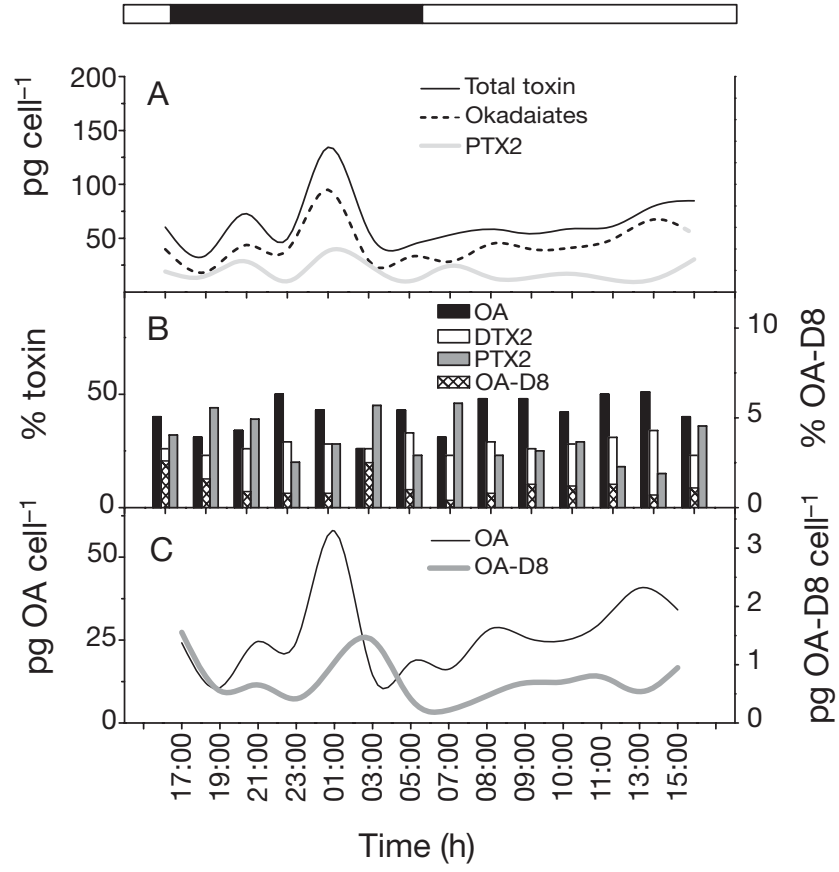

Fig. 10. Hourly distribution of: (A) total toxin (okadaiates + PTX2) per cell; (B) percentage of OA, DTX2, PTX2 and OA-D8 in relation to total toxin content per cell shown in (A); (C) variability of the OA and OA-D8 cell quota. Horizontal bar on top indicates light and dark hours

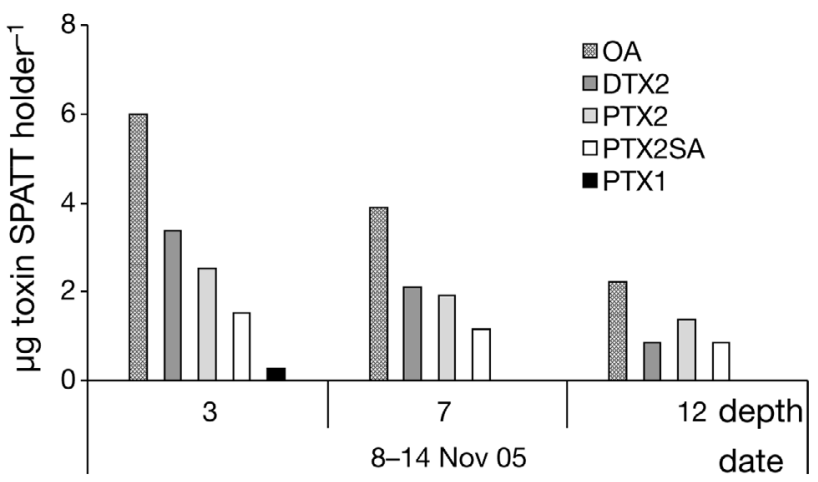

Fig. 12. Cumulative adsorption of polyether biotoxins on the resin containers from 8 to 14 November 2005 at 3, 7 and $12 \mathrm{~m}$ depth at Stn P2 (Ría de Pontevedra)

maximum of $D$. acuta cell concentration. The lack of cellular division $\left(\mu=0.024 ; \mu_{\min }=0.03 \mathrm{~d}^{-1}\right)$ together with frequencies of up to $15 \%$ of lysed cells suggests that it was an aged population of $D$. acuta with a negative net growth rate, i.e. starting its phase of exponential decline, at an exceptionally late time of the year. Reports from the Galician Monitoring Centre the following week confirmed a quick decline of D. acuta, to cell levels around 200 cells $\mathrm{l}^{-1}$ in all the rías. These 
results also confirm the view that the high cellular concentrations observed were due to physical accumulation resulting from along-shore and cross-shelf transport of shelf populations into the rías associated with downwelling-promoting winds (Escalera et al. 2006a).

In previous Dinophysis acuta daily cycle studies conducted in the area in 1994 and 1997 (in mid and late October respectively), in situ division rate $(\mu)$ estimates were considerably higher $\left(\mu=0.65 \mathrm{~d}^{-1}\right.$ and $\mu_{\min }=$ $0.20 \mathrm{~d}^{-1}$ in $1994 ; \mu=0.33 \mathrm{~d}^{-1}$ and $\mu_{\min }=0.17 \mathrm{~d}^{-1}$ in 1997) (Reguera et al. 2003). Nevertheless, phased-cell division and a common cell cycle pattern, with maximum frequency of dividing + recently divided cells $2 \mathrm{~h}$ after sunrise, were also observed during this study. Both in 1994 (temperature $>16^{\circ} \mathrm{C}$, salinity $>34.5 \mathrm{psu}$ ) and 1997 (temperature $>17^{\circ} \mathrm{C}$, salinity $>35.2$ ), physical conditions in the top $10 \mathrm{~m}$ were quite different from those observed during this bloom (surface temperature = $15.4^{\circ} \mathrm{C}$, salinity $=32.5$ to $34 \mathrm{psu}$ ), which occurred very late in the year, and after the onset of winter temperature reversal (Fig. 2A).

Dinophysis acuta cells did not exhibit a migratory behaviour during the diel cycle. Nevertheless, the cell maxima at each vertical profile coincided with the depth of the maximum density discontinuity. Vertical heterogeneities (in terms of cellular density) were more marked at the beginning of the study, at low tide, when density gradients were highest. Cells appeared more dispersed after low tide. Therefore, the tidal cycle seemed to affect the diurnal variability in surface cell distribution. $I_{p}$ values $>1$ would indicate an aggregated pattern of $D$. acuta cells in the surface in addition to the effects of tidal cycle and density gradients.

Despite the practical absence of division and a considerable percentage of dead individuals, D. acuta cells appeared aggregated near the surface and at the depth of maximum density discontinuities. Therefore, aggregation of Dinophysis cells can take place even within senescent, non-dividing populations.

\section{Vacuolation and starch content}

Cells of Dinophysis acuta exhibiting strong reddish pigmentation and full of digestive vacuoles have been reported before in the Galician Rías, but their frequency was not quantified either through their seasonal growth or through a daily cycle. Controversy exists on whether the phycoerythrin-containing plastids of Dinophysis are constitutive or are kleptoplastids acquired from their prey, but ingestion of prey in cultures of $D$. acuminata is followed by observation of vacuolation (Park et al. 2006). It is not known if phycoerythryn-containing ciliates are the only possible prey for Dinophysis spp., but single cell isolates of D. acuminata full of digestive vacuoles can undergo several divisions in laboratory incubations without addition of live prey (Reguera et al. unpubl. data). Therefore, the practical absence of digestive vacuoles during this daily cycle (Fig. 3 ) indicates that D. acuta, which presented the highest cell toxin quota of the season, had not been feeding recently on ciliate prey.

Changes in the frequency of starch-containing cells observed in this study during a diel cycle (with minimum values at the end of the night) suggest that starch production is linked to photosynthesis. Nevertheless, results presented here are not in full agreement with those of Seo \& Fritz (2002), who found a total lack of starch granules in cultures of the marine dinoflagellates Lingulodinium polyedrum (Stein) Dodge and Pyrocystis lunula (Schütt) Schütt during night time, but a continuous presence in 2 freshwater species. In any case, a high proportion of Dinophysis acuta cells in this study exhibited orange autofluorescence and contained starch granules, suggesting a potential for photosynthesis and production of starch (Figs. $3 \& 4$ ). The physiological role of starch granules in Dinophysis spp. is not known. It is possible cells containing starch granule reserves, but no signs of division, were in some kind of quiescent mode prior to overwintering conditions. Unfortunately, cell staining with fluorescein diacetate (FDA, Selvin et al. 1988), which is now routinely used in our laboratory to estimate frequencies of viable cells of Dinophysis spp. under the epifluorescent microscope (González-Gil et al. 2006), was not used during this sampling. Future results will determine if percentages of non-viable cells obtained from FDAstained cells parallel those of cells with no autofluorescence.

\section{Toxin profile of Dinophysis acuta during the daily cycle}

OA, DTX2 and PTX2 have been reported as the main toxin components in different populations of Dinophysis acuta from Galicia (Fernández et al. 2001, Fernández et al. 2006) and this species was associated with the occurrence of DTX2 and PTXs in Galician and Portuguese shellfish (Vale 2004). Results shown here constitute the first report, based on LC-MS analyses, of the occurrence of OA-diol esters in D. acuta from Europe, although the presence of these compounds had been previously suspected in Galician populations of D. acuminata (Moroño et al. 2003) and D. acuta (Fernández et al. 2006). However, estimates of OA-D8 in this study are semiquantitative and have to be taken with caution because an inappropriate standard was used for quantification. 
The constant OA:DTX2 ratio (3:2) observed during this study agrees with previous observations by Fernández et al. (2001) and Vale (2004) in single cell isolates and in net hauls rich in Dinophysis acuta in Galicia and Portugal. In contrast, the proportion of PTX2 in relation with free okadaiates was variable, and in 2 samples during the cycle, PTX2 was the dominant toxin. Therefore, the toxin profile of a population of a given species in a locality will be influenced by the time of sampling within the daily cycle. These findings suggest that the metabolism and release of these 2 groups of toxins, okadaiates and pectenotoxins, which have different chemical structures and biological effects, exhibit different biological rhythms, use a different biosynthetic pathway and/or, respond to environmental conditions in a different way.

\section{Changes of cell toxin quota of Dinophysis acuta during the daily cycle}

Ranges of OA, DTX2 and PTX2 content per cell (11 to 58,8 to 37 , and 10 to $38 \mathrm{pg} \mathrm{cell}^{-1}$, respectively) estimated from phytoplankton rich in Dinophysis acuta during this study were within ranges reported from New Zealand (Suzuki et al. 2004, MacKenzie et al. 2005) and Portugal (Vale 2004) for the same species. However, levels of OA and DTX2 were much higher than previous reports from Galicia (Fernández et al. 2001, Fernández et al. 2006). The maximum concentration of OA was similar to and that of DTX2 about half of the values reported for D. acuta in Ireland (58 to 85 and 77 to $80 \mathrm{pg} \mathrm{cell}^{-1}$, respectively) (Fernández-Puente et al. 2004). Maximum PTX2 levels found in this study were 35 to $46 \%$ of those found in D. acuta from New Zealand (MacKenzie et al. 2005).

Throughout the daily cycle, a 5-fold variation was observed in the cell toxin quota of OA and DTX2, a 4 -fold variation in that of PTX2, and a 2-fold variation in OA-D8. If the total cell toxin quota is considered, the range of variability (34 to $134 \mathrm{pg}$ cell $^{-1}$ ) shows a 4 -fold difference between maximum and minimum values.

Cell disruption or even toxin release due to stress may lead to toxin leakage from the plankton slurries collected on meshes during the filtration processes (Johansen \& Rundberget 2006). Plankton collection and filtration for toxin analyses during this study were carried out as rapidly as possible, and in the same manner for each sampling point, but some losses for the reasons mentioned before cannot be ruled out. Leaching of toxins during manipulation cannot be avoided unless alternative methods are developed that allow rapid fixation, to seal the cell walls, before sorting the target species by microcapillarity.

\section{Considerations on diol-ester production by Dinophysis acuta}

OA diol-esters have been identified in Dinophysis acuta from New Zealand (Suzuki et al. 2004) but their sulphated forms have not been reported within Dinophysis spp. In cultures of the epibenthic dinoflagellate Prorocentrum maculosum Faust, DTX5a and DTX5blike sulphated esters are derived from enol-esters with C7 and C8 side chains, respectively (Hu et al. 1995a), whereas in cultures of $P$. belizeanum Faust (which produces an ester with a C10 side chain) the sulphated form produced was DTX5c (Cruz et al. 2006). DTX4, another sulphated form derived from OA-D8, was found in cultures of $P$. lima (Hu et al. 1995b). Therefore, the sulphated esters likely to be found in D. acuta cells with the toxin profile shown here are DTX4 and DTX5b. However, these forms were not detected in the methanol extracts during this study.

OA diol-esters can be formed from partial hydrolysis of sulphated esters by an esterase of planktonic origin; this enzymatic transformation can be accelerated by the extraction protocols (Hu et al. 1995b). Boiling to inhibit enzymatic transformations in the samples (Quilliam et al. 1996) was not carried out during this work and there is a possibility that the OA-D8 detected in Dinophysis acuta originated from DTX5b or DTX4 OA-sulphated derivatives. However, if sulphated forms of OA in the samples had suffered enzymatic hydrolisis during collection, at least trace amounts of these toxins should be present and easy to detect in the chromatograms (Quilliam et al. 1996). Further, DTX5c was detected, purified and characterized from unboiled Prorocentrum belizeanum cultures (Cruz et al. 2006). Our samples were handled with extreme care and the plankton concentrates resuspended in methanol on board immediately after collection. This procedure would minimize the conversion of DTX5b and DTX4 into diol-esters. Moreover in this study, increases in OA-D8 cell quota were always observed to coincide with or follow a rise in OA cell quota (Fig. 9C). These results suggest that in the natural populations of $D$. acuta analyzed during this study, sulphated forms of OA did not occur as a final metabolite.

The occurrence of sulphated forms of OA is not a common feature in cultures of epibenthic Prorocentrum spp. Absence of sulphated forms was confirmed in cultures of $P$. lima (strain PL2V) (Paz et al. 2007). In contrast, large amounts of DTX5c-like sulphated toxins were found in cultures of $P$. belizeanum (strain PBMA01) grown under the same experimental conditions and with the application of identical toxin-extraction procedures (Cruz et al. 2006). These results led the latter authors to the hypothesis that diol-esters are 
intermediate forms, derived from OA, which may give way to sulphated compounds as final products following an elongation of the side chain of OA. Methylation of OA diol-ester to OA methyl-ester by enzymatic hydrolysis, which can be detected as $[\mathrm{M}+\mathrm{H}]^{+}$ions at $\mathrm{m} / \mathrm{z}$ 819.5, has been reported by Quilliam et al. (1996) in $\mathrm{MeOH}: \mathrm{H}_{2} \mathrm{O}$ (4:6) extracts from P. lima cultures. These authors found that enzymatic conversion was reduced by lowering the proportion of water in the extraction solution. However, adducts corresponding to these methylated forms were not detected in our samples, where most of the water was eliminated from the slurry resuspended in methanol.

\section{Toxin release from Dinophysis acuta cells}

Rapid changes in $Q_{t}$ observed during the daily cycle (Fig. 11) suggest that some toxins are either released to the seawater, or readily transformed to unknown intracellular diol-ester-like compounds, different from OA-D8. Therefore, the decline of OA + DTX2 toxin- $\mu$ in relation to OA-D8 toxin- $\mu$ shown in Fig. 11 suggests a previous transformation of OA to OA-D8, whereas a decline in diol-ester toxin- $\mu$ could indicate a transformation to another unknown diol-ester, or a release in the form of OA-D8.

Sulphated esters were proposed to be the natural storage product in $P$. lima cultures to avoid auto-toxicity; these compounds are also more easily excreted from the cell (Hu et al. 1995b). Large amounts of dissolved lipophilic toxins were collected in situ by the adsorbing resins during the week when the present experiment was carried out (Fig. 12). Nevertheless, with the available data, it is not possible to determine the chemical forms of the released toxins, or to ascertain whether the toxins were actively released from Dinophysis, from other marine organisms or resulted from cell lysis.

PTX2SA results from metabolic transformation of PTX2 within bivalve tissues (Suzuki et al. 2001) as a kind of detoxification mechanism (Miles et al. 2004b). However, PTX2SA may also be formed from PTX2 released from live or lysed cells of Dinphysis acuta transformed by enzymes secreted by planktonic organisms. Thus, PTX2SA adsorbed by the resins may have either been directly released by mussels from the rafts nearby, or resulted from enzymatic transformations of toxins released from either dead cells of D. acuta or other live planktonic organisms. To date, PTX1 has only been reported as a metabolic transformation of PTX2 within Japanese scallops (Suzuki et al. 1998). Production of PTX1 by mussels, the overwhelmingly dominant bivalve in the Galician Rías, has not been described; therefore, with the available data it is not possible to dilucidate the origin of the PTX1 adsorbed in our resin holders.

The total amount of okadaiates adsorbed at the 3 sampling depths were up to 1 order of magnitude higher than those found in SPATT holders exposed for the same number of days to Dinophysis blooms in New Zealand $(0.23 \mu \mathrm{g}$ of OA+DTX1) at $9 \mathrm{~m}$ (MacKenzie et al. 2004), but amounts of PTX2 $(2.5 \mu \mathrm{g})$ were quite similar. In the present study, maximum values of adsorbed toxins at $3 \mathrm{~m}$ reflect well the depth range where $D$. acuta cell maxima were detected during this experiment.

\section{Dynamic aspects of daily variation in cell toxin quota of Dinophysis acuta}

Changes in cell toxin quota during this fieldwork did not appear to be associated with variability in cell size and/or dilution by cell division. Therefore, these changes should be explained in connection with possible circadian rhythms in toxin metabolism. The maximum cell toxin quota occurred at 01:00 h, $8 \mathrm{~h}$ after sunset. If cellular division was practically zero, most cells must have been either in phase G1 of their cell cycle, or in a sort of quiescent G0 phase corresponding to overwintering cells. These results disagree with those reported in the literature for epibenthic lipophilic toxin-producers of the genus Prorocentrum, where toxin production was restricted to the day (Pan et al. 1999). Further, the sequence of changes in cell toxin quota for different toxins in $D$. acuta does not coincide with previous observations on $P$. lima cultures, where the increase of OA, DTX1 and OA-D8 usually occurred in daylight, during the $\mathrm{S}$ and $\mathrm{G} 2$ phases, 3 to $6 \mathrm{~h}$ after the increase of DTX4 during the G1 cell phase (Pan et al. 1999). Results of the present study suggest that toxin production in Dinophysis acuta cannot be strictly coupled to daylight, and that synthesis of OA-derivatives could not be initiated from an ester.

In Norwegian coastal waters, substantial amounts of OA and PTX2 in the heterotrophic dinoflagellate Protoperidinium divergens (Ehrenberg) Balech, and smaller amounts of PTX2 in P. crassipes (Kofoid) Balech and P. depressum (Bailey) Balech - presumably originating from their prey organisms - were found in single cell isolates of these species (Miles et al. 2004b). These Protoperidinium spp. were present in our plankton concentrates (see Table 1), and may have led to an overestimation in the toxin content per cell of Dinoph$y$ sis. This possibility is most likely during the peak hour for total cell toxin content (01:00 h, Fig. 10A), when the percentage of Protoperidinium spp. (10\%) was maximum. However, changes observed in total cell toxin quota did not correlate well with those in the abundance of Protoperidinium spp. 
An important observation to highlight here is that the cell toxin quota of Dinophysis acuta found during this field work was the highest observed since the initiation of the bloom. It coincided with the stationary early exponential decline phase of the population growth (Escalera et al. 2006a), with cessation of cellular division and a considerable proportion of dead cells.

Increased cell toxin quota in dinoflagellate cultures can be interpreted as an imbalance between division rate (that dilutes toxin content per cell) and toxin production rate (Anderson et al. 1990, Flynn \& Flynn 1995). In cultures of Alexandrium fundyense Balech, growth inhibition induced by turbulence led to an increase in cell toxin quota. Nevertheless, the tolerance threshold to turbulence levels has to be considered on a species-specific basis (Berdalet \& Estrada 2005).

Field studies with Dinophysis acuta and D. acuminata in 2 Swedish fjords showed that toxin content per cell was inversely proportional to population density (Lindahl et al. 2007). In that study, information on division rates was not provided, but the high-density populations were located in the pycnocline in a fjord with restricted circulation. It could well be that the high numbers in Lindahl et al. (2007) resulted from active in situ division, in contrast with the mature $D$. acuta population described here, which increased from physical accumulation and exhibited no cellular division at the end of its growing season after onset of winter conditions.

In summary, this study illustrates variability in behaviour, no migration to aggregation in the top $5 \mathrm{~m}$, and describes cellular characteristics, toxin profile and cell toxin quota in a senescent population of Dinophysis acuta. This population reached maximum cellular densities and cell toxin quota at the end of its growing season, coinciding with cessation of division, a high percentage of dead cells and cells with starch granules, and no evidence of recent feeding on live prey. These results, quite distinct from those obtained from the same population at the initiation of the bloom - when low cellular density, high division rate, low cell toxin quota and aggregation in the thermocline region were the norm - show the importance of parameterization of physiological and behavioural processes during different phases of the population growth and hydrodynamic conditions.

Acknowledgements. We are grateful to the crew of RV 'J. M. Navaz' for their helpful attitude, to Pilar Rial and Isabel Ramilo for technical assistance, to Beatriz Paz and Lourdes Velo for their help with preparation of figures, and to the Galician Monitoring Programme (INTECMAR) for continuous supply of information on phytoplankton and phycotoxins in the Galician Rías. Thanks to Dr. Philip Hess for providing us with DTX2, Dr. Chris Miles for PTX2 seco-acid and DTX1, Dr. Javier Fernández for OA-D8 diol ester, and Prof. Takeshi Yasumoto for PTX1 reference material. This research was supported by projects 'Dinophysis Galicia' (CTM2004-0478CO3-01) and 'HABIT' (EU GOCE-CT-2005-003932) to B.R. and project AGL 2005-07924-C04-02 to J.M.F. G.P. was funded by a Chilean pre-doctoral fellowship from the Centro de Estudios del Quaternario Fuego-Patagonia y Antartica (CEQUA) Foundation and the Instituto de Fomento Pesquero (IFOP). This is a contribution to the GEOHAB-Core Research Projects HABs in Stratified Systems, HABs in Upwelling Systems and HABs in Fjords and Coastal Embayments.

\section{LITERATURE CITED}

Anderson DM, Kulis DM, Sullivan JJ, Hall S, Lee C (1990) Dynamics and physiology of saxitoxin production by the dinoflagellates Alexandrium spp. Mar Biol 104:511-524

Bai X, Adolf JE, Bachvaroff T, Place AR, Coats DW (2007) The interplay between host toxins and parasitism by Amoebophrya. Harmful Algae 6:670-678

Berdalet E, Estrada M (2005) Effects of small-scale turbulence on the physiological functioning of marine algae. In Subba Rao DV (ed) Algal cultures, analogues and applications. Science Publishers, Enfield, NH, p 459-500

Blanco J, Fernández ML, Mariño J, Reguera B, Miguez A and others (1995) From Dinophysis spp. toxicity to DSP outbreaks: a preliminary model of toxin accumulation in mussels. In: Lassus P, Arzul G, Erard-Le Denn E, Gentien P, Marcaillou-Le Baut C (eds) Harmful marine algal blooms. Lavoisier, Paris, p 777-782

Carpenter EJ, Chang J (1988) Species-specific phytoplankton growth rates via diel DNA synthesis cycles. I. Concept of the method. Mar Ecol Prog Ser 43:105-111

Carpenter JE, Janson S, Boje R, Pollehne F, Chang J (1995) The dinoflagellate Dinophysis norvegica: biological and ecological observations in the Baltic Sea. Eur J Phycol 30: $1-9$

Cruz P, Daranas A, Fernández J, Souto M, Norte M (2006) DTX5c, a new OA sulphate ester derivative from cultures of Prorocentrum belizeanum. Toxicon 47:920-924

Escalera L, Reguera B, Moita T, Pazos Y, Moroño A, Cerejo M and others (2006a) Follow up of an autumn bloom of Dinophysis acuta in NW Iberia: along-shore transport versus in situ growth. Programme and Abstracts of the XII International Conference on Harmful Algae, Copenhagen, p 169. Available at: www.bi.ku.dk/hab/docs/P\&A_Book.pdf

Escalera L, Reguera B, Pazos Y, Moroño A, Cabanas JM (2006b) Are different species of Dinophysis selected by climatological conditions? Afr J Mar Sci 28(2):283-288

Fernández ML, Reguera B, Ramilo I, Martínez A (2001) Toxin content of Dinophysis acuminata, D. acuta and D. caudata from the Galician Rías Bajas. In: Hallegraeff GM, Blackburn SI, Bolch CJ, Lewis RJ (eds) Harmful algal blooms. Intergovernmental Oceanographic Commission of UNESCO, Paris, p 360-363

Fernández ML, Reguera B, González-Gil S, Míguez A (2006) Pectenotoxin-2 in single-cell isolates of Dinophysis caudata and Dinophysis acuta from the Galician Rías (NW Spain). Toxicon 48:477-490

Fernández-Puente P, Fidalgo Sáez MJ, Hamilton B, Furey A, James KJ (2004) Studies of polyether toxins in the marine phytoplankton, Dinophysis acuta in Ireland using multiple tandem mass spectrometry. Toxicon 44:919-926

Figueiras FG, Jones KJ, Mosquera AM, Álvarez-Salgado XA, Edwards A, MacDougall N (1994) Red tide assemblage 
formation in an estuarine upwelling ecosystem: Ría de Vigo. J Plankton Res 16(7):857-878

Flynn KJ, Flynn K (1995) Dinoflagellate physiology: nutrient stress and toxicity. In: Lassus P, Arzul G, Erard-Le Denn E, Gentien P, Marcaillou-Le Baut C (eds) Harmful marine algal blooms. Lavoisier, Paris, p 541-550

Fraga S, Anderson DM, Bravo I, Reguera B, Steidinger KA, Yentsch CM (1988) Influence of upwelling relaxation on dinoflagellates and shellfish toxicity in Ría de Vigo, Spain. Estuar Coast Shelf Sci 27:349-361

Gisselson LA, Carlsson P, Granéli E, Pallon J (2002) Dinophysis blooms in the deep euphotic zone of the Baltic Sea: do they grow in the dark? Harmful Algae 1:401-418

González-Gil S, Velo L, Reguera B (2006) Ecological and physiological studies of Dinophysis spp. during an upwellingdownwelling cycle in Ría de Pontevedra (NW Spain). Programme and Abstracts of the XII International Conference on Harmful Algae, Copenhagen, p 180. Available at: www. bi.ku.dk/hab/docs/P\&A_Book.pdf

$\mathrm{Hu}$ T, Curtis JM, Walter JA, McLachlanb JL, Wright JLC (1995a) Two new water-soluble DSP toxin derivatives from the dinoflagellate Prorocentrum maculosum: Possible storage and excretion products. Tetrahedron Lett 36: 9273-9276

Hu T, Curtis J, Walter JA, Wright JLC (1995b) Identification of DTX-4, a new water-soluble phosphatase inhibitor from the toxic dinoflagelate Prorocentrum lima. J Chem Soc Chem Commun:597-599

Iwasaki J (1986) The mechanism of mass occurrence of Dinophysis fortii along the coast of Ibaraki Prefecture. Bull Tohoku Reg Fish Res Lab 48:125-136

Jacobson DM, Andersen RA (1994) The discovery of mixotrophy in photosynthetic species of Dinophysis (Dinophyceae): light and electron microscopical observations of food vacuoles in Dinophysis acuminata, D. norvegica and two heterotrophic dinophysoid dinoflagellates. Phycologia 33:97-110

Johansen M, Rundberget T (2006) The sampling technique greatly affects the toxin content in Dinophysis spp. cells. Programme and Abstracts of the XII International Conference on Harmful Algae, Copenhagen, p 200. Available at: www.bi.ku.dk/hab/docs/P\&A_Book.pdf

Kamykowski D, Yamazaki H, Yamazaki AK, Kirkpatrick GJ (1998) A comparison of how different orientation behaviours influence dinoflagellate trajectories and photoresponses in turbulent water columns. In: Anderson DM, Cembella AD, Hallegraeff GM (eds) Physiological ecology of harmful algal blooms. NATO ASI series, Series G, Ecological sciences 41, Springer-Verlag, Berlin, p 581-599

Koike K, Koike K, Takagi M, Ogata T, Ishimaru T (2000) Evidence of phagotrophy in Dinophysis fortii (Dinophysiales, Dinophyceae), a dinoflagellate that causes diarrhetic shellfish poisoning (DSP). Phycol Res 48:121-124

Krebs CJ (1989) Ecological methodology. Harper Collins, New York

Lindahl O, Lundve B, Johansen M (2007) Toxicity of Dinophysis spp. in relation to population density and environmental conditions on the Swedish west coast. Harmful Algae 6:218-231

MacKenzie L, Beuzenberg V, Holland P, McNabb P, Selwood A (2004) Solid phase adsorption toxin tracking (SPATT): a new monitoring tool that simulates the biotoxin contamination of filter feeding bivalves. Toxicon 44:901-918

MacKenzie L, Beuzenberg V, Holland P, McNabb P, Suzuki T, Selwood A (2005) Pectenotoxin and okadaic acid-based toxin profiles in Dinophysis acuta and Dinophysis acumi- nata from New Zealand. Harmful Algae 4:75-85

Maestrini SY (1998) Bloom dynamics and ecophysiology of Dinophysis spp. In: Anderson DM, Cembella AD, Hallegraeff GM (eds) Physiological ecology of harmful algal blooms. Springer-Verlag, Berlin, p 243-266

Miles CO, Wilkins AL, Munday R, Dines $\mathrm{MH}$ and others (2004a) Isolation of pectenotoxin-2 from Dinophysis acuta and its conversion to pectenotoxin-2 seco acid, and preliminary assessment of their acute toxicities. Toxicon 43: $1-9$

Miles CO, Wilkins AL, Samdal IA, Sandvik M and others (2004b) A novel Pectenotoxin, PTX-12, in Dinophysis spp. and shellfish from Norway. Chem Res Toxicol 17: 1423-1433

Moita MT, Sobrinho-Gonçalves L, Oliveira PB, Palma S, Falcão M (2006) A bloom of Dinophysis acuta in a thin layer off North-West Portugal. Afr J Mar Sci 28(2):265-269

Moroño A, Arevalo F, Fernandez ML, Maneiro J, Pazos Y, Salgado C, Blanco J (2003) Accumulation and transformation of DSP toxins in mussels Mytilus galloprovincialis during a toxic episode caused by Dinophysis acuminata. Aquat Toxicol 62:269-280

Olenina I, Hajdu S, Edler L, Andersson A and others (eds) (2006) Biovolumes and size-classes of phytoplankton in the Baltic Sea, Vol HELCOM Balt Sea Environ Proc No 106

Pan Y, Cembella AD, Quilliam MA (1999) Cell cycle and toxin production in the benthic dinofagellate Prorocentrum lima. Mar Biol 134:541-549

Park MG, Kim S, Kim HS, Myung G, Kang YG, Yih W (2006) First successful culture of the marine dinoflagellate Dinophysis acuminata. Aquat Microb Ecol 45:101-106

Paz B, Daranas AH, Cruz PG, Franco JM, Pizarro G, Souto ML, Norte M, Fernández JJ (2007) Characterization of okadaic acid related toxins by liquid chromatography coupled with mass spectrometry. Toxicon 50:225-235

Quilliam MA, Hardstaff WR, Ishida N, McLachlan JL, Reeves AR, Rose NW, Windust AJ (1996) Production of Diarrhetic Shellfish Poisoning (DSP) toxins by Prorocentrum lima in culture and development of analytical methods. In: Yasumoto T, Oshima Y, Fukuyo Y (eds) Harmful and toxic algal blooms. Intergovernmental Oceanographic Commission of UNESCO, Sendai, p 289-292

Reguera B, Bravo I, Fraga S (1995) Autoecology and some life history stages of Dinophysis acuta Ehrenberg. J Plankton Res 17:999-1015

Reguera B, Garcés E, Pazos Y, Bravo I, Ramilo I, González-Gil S (2003) Cell cycle patterns and estimates of in situ division rates of dinoflagellates of the genus Dinophysis by a postmitotic index. Mar Ecol Prog Ser 249:117-131

Reguera B, Pizarro G (2007) Planktonic dinoflagellates which produce polyether toxins of the old 'DSP complex'. In: Botana, L (ed) Seafood and freshwater toxins: pharmacology, physiology and detection, 2nd edn. Taylor \& Francis, London, p 257-284

Selvin R, Reguera B, Bravo I, Yentsch CM (1988) Use of Fluorescein Diacetate (FDA) as a single-cell probe of metabolic activity in dinoflagellate cultures. Biol Oceanogr 6: 505-511

Seo KS, Fritz L (2002) Diel changes in pyrenoid and starch reserves in dinoflagellates. Phycologia 41:22-48

Setälä O, Autio R, Kuosa H, Rintala J, Ylöstalo P (2005) Survival and photosynthetic activity of different Dinophysis acuminata populations in the northern Baltic Sea. Harmful Algae 4:337-350

Suzuki T, Mitsuya T, Matsubara H, Yamasaki M (1998) Determination of pectenotoxin-2 after solid-phase extraction from seawater and from the dinoflagellate Dino- 
physis fortii by liquid chromatography with electrospray mass spectrometry and ultraviolet detection. Evidence of oxidation of pectenotoxin-2 to pectenotoxin- 6 in scallop. J Chromatogr A 815:155-160

Suzuki T, MacKenzie L, Stirling D, Adamson J (2001) Pectenotoxin-2 seco acid: a toxin converted from pectenotoxin-2 by the New Zealand Greenshell mussels, Perna canaliculatus. Toxicon 39:507-514

Suzuki T, Beuzenberg V, MacKenzie L, Quilliam MA (2004) Discovery of okadaic acid esters in the toxic dinoflagellate Dinophysis acuta from New Zealand using liquid chromatography/tandem mass spectrometry. Rapid Commun Mass Spectrom 18:1131-1138

Vale P (2004) Differential dynamics of dinophysistoxins and pectenotoxins between blue mussel and common cockle: a phenomenon originating from the complex toxin profile of

Editorial responsibility: Howard Browman (Associate Editorin-Chief), Storebø, Norway
Dinophysis acuta. Toxicon 44:123-134

Vale P, Sampayo MA (2002) Pectonotoxin-2 seco acid, 7-epipectenotoxin-2 seco acid and pectonotoxin-2 in shellfish and plankton from Portugal. Toxicon 40:979-987

Van Trijp JMP, Roos AH (1991) Model for the calculation of calibration curves. RIKILT Report 91.02, Wageningen, p 1-4

Vaulot D (1992) Estimate of phytoplankton division rates by the mitotic index method: The $f_{\max }$ approach revisited. Limnol Oceanogr 37:644-649

Villarino ML, Figueiras FG, Jones KJ, Alvarez-Salgado XA, Richard J, Edwards A (1995) Evidence of in situ diel vertical migration of a red-tide microplankton species in Ría de Vigo (NW Spain). Mar Biol 123:607-617

Yih W, Kim HS, Jeong HJ, Myung G, Kim YG (2004) Ingestion of cryptophyte cells by the marine photosynthetic ciliate Mesodinium rubrum. Aquat Microb Ecol 36:165-170

Submitted: March 28, 2007; Accepted: July 29, 2007

Proofs received from author(s): December 7, 2007 